\title{
Biometrika Trust
}

Anomalies of Pigmentation Among Natives of Nyasaland: A Contribution to the Study of Albinism

Author(s): Hugh Stannus Stannus

Source: Biometrika, Vol. 9, No. 3/4 (Oct., 1913), pp. 333-365

Published by: Biometrika Trust

Stable URL: http://www.jstor.org/stable/2331897

Accessed: 19/06/2014 18:21

Your use of the JSTOR archive indicates your acceptance of the Terms \& Conditions of Use, available at http://www.jstor.org/page/info/about/policies/terms.jsp

JSTOR is a not-for-profit service that helps scholars, researchers, and students discover, use, and build upon a wide range of content in a trusted digital archive. We use information technology and tools to increase productivity and facilitate new forms of scholarship. For more information about JSTOR, please contact support@jstor.org. 


\title{
ANOMALIES OF PIGMENTATION AMONG NATIVES OF NYASALAND.
}

\section{A CONTRIBUTION TO THE STUDY OF ALBINISM*.}

\author{
By HUGH STANNUS STANNUS, M.D. Lond., etc.
}

\section{Classification.}

ON page 148 of Part I of the Monograph on Albinism by Pearson, Nettleship and Usher from the Department of Applied Statistics, University College, London (Dulau \& Co.), 1911, Professor Karl Pearson remarks, after dealing with some cases of albinism reported by myself and embodied in that work, "It is impossible to study Dr Stannus's data without being impressed with the various grades of albinism to be found in the dark races." It is particularly with the wish of drawing attention to this point that I now publish notes on cases of albinism which have come under my notice since the appearance of the above monograph. Pearson notices that there appears to be a greater variation in the albinotic characters among dark-skinned peoples, and seems inclined to attribute it to the fact that the various lesser grades of albinism are more readily distinguished among them than among fair races. With this I agree, and, as my own cases will show, intermediate forms between more or less well-marked types are found in numbers. This is a matter which I think has largely escaped the observation of those who have published records of cases. I am of opinion that for this reason consideration of the observations made by a single individual on a number of cases from a single country is more likely to give a correct impression of the subject than a mass of material drawn from many sources.

The difficulty in defining albinism lies in the fact that short of a microscopical examination of all the tissues of the body it is impossible to say whether pigment is present or not. Dealing with the tissues more especially concerned in albinism,

* This paper formed part of a thesis presented for the degree of Doctor of Medicine at the University of London. [The absence of Dr Stannus in Nyasaland has thrown upon the Editor the responsibility of editing these pages for press. Names have not always been spelt uniformly in the type-written manuscript, and at various other points the Editor has badly needed Dr Stannus' help. The Editor has ventured to add a few footnotes in square brackets on topics, which he would much preferred to have previously discussed with the author. ED.]

Biometrika Ix 


\section{Anomalies of Pigmentation among Natives of Nyasaland}

that is, those tissues which normally contain sufficient pigment to be evident to the unaided eye, it has been found that, even when they appear to contain none to the unaided eye, on microscopical examination a certain amount of pigment may be present; such has been demonstrated in the case of the eye and hairs.

Pearson divides albinotic negroes into the following classes:

(I) Complete albino.

(II) The spotted (freckled) albino.

(III) The blue-eyed white-skinned negro with photophobia and nystagmus but not red pupils.

(IV) The yellow-eyed white-skinned negro.

(V) Xanthous negro.

(VI) The partial albino or piebald negro.

Considerable confusion I think has arisen over the matter of the colour of the eye, which in my opinion invalidates some descriptions and also probably the above classification. "Eyes said to have the pinkish colour common to albinos," "the eyes are pink," are expressions commonly found in reading descriptions. Again, Sir H. Johnston in referring to Nyasaland writes, "cases of Albinism when the hair is yellowish white, the iris of the eye pink and the body skin an unwholesome-looking, reddish white are not common." When I say that I have collected a very large number of albinos in that country and that I have never seen a case presenting this characteristic of the iris, I think it may be assumed that in this case as in some others a lack of precise observation has led Sir $\mathrm{H}$. Johnston to make an incorrect statement.

The same is, I think, true of a number of the loose statements made by other persons. They know that in typical European albinos and in, say, white mice the eye is "pink," and when they see a native of A frica with white skin and hair in whom it is difficult to get a proper view of the eye owing to nystagmus and photophobia they assume that the "eye is pink."

Dr Turner in describing cases of albinism seen in S. Africa, does not specify the colour of the irides and pupil in individual cases but refers only in general terms to the peculiar pink colour of the pupil, yet from the context it is evident he is speaking of the red reflex obtained through the pupils with the use of artificial light, though Pearson does not make this point clear.

The point I wish to emphasize is that in all cases noted by myself, when seen in ordinary daylight the pupil appears black and there is no red colour seen through the pupils under these conditions as seen in European albinos. I believe this to be true of African albinos in general, though I do not altogether doubt the occurrence in rare instances of the other phenomenon. The explanation lies, I think, in the fact that absolute albinism of the eye in negroes is very rare and that the amount of pigmentation present is sufficient to prevent a large light entry and reflexion: that is to say, the number of complete negro albinos who 
will come under Pearson's Class (I) is very small, and this type is not found in Nyasaland at all events. He may on the other hand be referring to the presence of a "red reflex" obtained during ophthalmoscopical examination*.

When examined with artificial light and ophthalmoscopic mirror, all those of my cases approaching complete albinism show a "red reflex," differing from the dull red grey in the normal native in being brighter and devoid of the element of grey to a variable extent; and in some the brightness being greater than in the ordinary European, simulating that in a European albino.

The reason of the absence of light reflex (red pupil) in daylight is I believe due to the impediment to sufficient light entry caused by pigment on the posterior surface of the iris as much as to light absorption by pigment in the choroid.

In all my cases approaching the condition of complete albinism the irides are of a liquid steel blue grey colour, in some associated with a peripupillary ring of orange colour.

This I find corresponds to the descriptions given by observers in other parts of Africa whose writings bear the impress of being the result of careful observation.

I have considered these points at some length as I do not feel that the working classification given by Pearson clearly defines itself.

In Class (III) what does " not red pupils" mean? Does it mean the pupil is not red in the sense that the white rat's is, or does the expression refer to cases in which no red reflex can be obtained with artificial light?

In which class are to be placed cases which though they give this red reflex, have blue irides, in (I) or (III)?

The brightness of the red reflex varies very considerably, and I shall therefore make out one class which includes all those cases with white skin, white and yellow white hair, pale blue grey irides which give with artificial illumination a red reflex of any degree as opposed to a grey one. I shall also include in the same group as a sub-class those albinos with the above characteristics in whom, in addition, there have developed spots of pigmentation, so called Spotted or Freckled Albinos; I do this because the condition is not uncommonly found in the albinos of this country beyond the age of infancy.

I think it may be of use to make a group under Class (IV), that is, cases with yellow eyes but white skin.

* II think Dr Stannus is incorrect at this point, the red reflex from negro albino eyes was noted in a number of cases even before the invention of the ophthalmoscope and has frequently been noted since by trained observers not using artificial light. Our albino dogs have eyes almost identical for amount of pigment with those of the albino negro, and in three cases out of four the observer thinks they have dark pupils, on the fourth occasion the red reflex is caught because the incidence of ordinary light is suitable. If four or five albino dogs are in a room together and they are then excited, any observer sees the reflex at all turns. My classification was, of course, a broad one but I think a serviceable one as it roughly graded the albino negro into two classes according to the intensity of ocular pigmentation, i.e. by manifest or non-manifest red reflex, observable by the traveller without apparatus. ED.]

$43-2$ 


\section{Anomalies of Pigmentation among Natives of Nyasaland}

Under my own Class (III) I shall consider cases of Xanthism as I understand that condition. Again I would refer to Sir H. Johnston's misleading remarks, "occasionally there are cases of positive Xanthism or a state of colouration similar in a much less degree to albinism-namely that wherein the colour of the skin and the iris of the eye is quite a light yellowish brown; this type is very much admired by the negroes." It is the last sentence which shows the incorrectness of the deduction, though this of course would not be appreciated by anyone who does not know the country.

The light coloured woman admired by natives has a yellow skin, a rather cold colour, with irides of a light brown, all the hair, however, is always black as in the average native. People of this colour are more common among certain tribesthe Achikunda, those of Senna on the Zambesi river, among the Yaos and the ruling families of Momberas Angoni-and I look upon this skin colour as a racial characteristic and not as a feature of Xanthism. Whether or not albinism is more commonly associated with such peoples I am unable to say, though Pearson thinks there is some reason to believe that blondism does exist side by side with albinism, occurring in the same districts and, it has been asserted, in the same stocks. This was first pointed out by Pritchard and has since been supported by Pearson, who quotes cases of men from Nyasaland observed by Turner in South Africa; the latter however remarks that these cases had "pubic hair brown," "in other cases the skin was a light rich red colour, wool on scalp a light yellow, the eyebrows and lashes reddish brown"; these cases I should immediately admit as cases of Xanthism but not those referred to by Sir H. Johnston, who does not mention hair colour and the skin colour of whose cases is yellow rather than reddish brown.

By Xanthism, then, I mean a condition characterised by a skin colour of reddish brown, red, or warm brown colour, scalp hair a golden or reddish brown, the same being true of the face and body hair, the irides being a light brown or hazel*.

Just as cases of imperfect albinism or partial albinism have to be recognised, so there are degrees in Xanthism, as in one of Turner's cases, but I look upon the distinctive points about the affection as the peculiar reddish "warm" colour of the skin, generally if not always associated with a similar colour of all or some of the hair; the yellow-skinned natives referred to above, though lighter in colour than many cases of true Xanthism, very seldorn freckle as Xanthous natives do.

Dr Turner has also observed a number of natives with light hair " or down" on the temples, a fact which Pearson seems to think should be taken as significant as one of the first signs of a lighter pigmentation. With those downy hairs I am perfectly conversant but believe them to be merely an overgrowth of lanugo hairs. These fine downy hairs moreover are found in many natives elsewhere on the

* [The difference between Dr Stannus and myself appears to be that while I speak of a red or yellowish red skin, red, brown or even yellowish brown hair and brown to yellow irides as cases of Xanthism, he excludes anything beyond golden brown in the hair, or beyond hazel in the irides. ED.] 
body; they are always of the lanugo type and generally so small as to pass unnoticed but they will be seen to be of a lighter colour, golden to brown, and are quite distinct from the curled "woolly" hairs of the body skin.

There is another type of skin pigmentation for which a class has to be made. I refer to cases which with a light brown skin colour, not red and not yellow, and light hazel irides, have hair of a dirty yellow colour but with no red tinge in it. Some of these cases have photophobia and nystagmus pointing to deficient pigment in the eye. Typical cases form a well-marked group though I shall later show there are no absolute distinctions to be made between any of the groups or classes and that intermediate cases are met with all along the line. This last class is characterised by the fact that at birth the skin and hair are practically white but that slow darkening has occurred. The same may have been true of the irides but native observation upon which I have had to depend mostly in these cases has not been sufficiently good to remark this point.

These cases resemble the remarkable case of Dr Ascherson's referred to by Graves and quoted by Pearson, and are, I think, akin to those described by the same author as occurring in Papuans and elsewhere, in which the skin is darker than in the first form (ordinary typical albino) and in which nystagmus may or may not be present, where freckling is absent or at any rate not conspicuous, while the hair is tow coloured. Similar cases have been reported from Malay.

I have considered above albinism of various degrees but always affecting the whole of the skin, hair and eyes, that is to say cases of complete and incomplete albinism. It now remains to deal with the condition in which the affection is limited in extent, what is termed Partial Albinism. According to the extent of the albinotic characters this class is sub-divided by Pearson into Piebalds and Spotlings; the leucosis may be complete or incomplete.

It is therefore a difficult matter when considering cases to be sure under which category any particular one should be placed. Some doubt was entertained as to the existence of Piebalds until quite recently, when Seligmann's Papuan case, Gilbert Smith's English case and a family I have described from Nyasaland established the undoubted existence of Piebaldism. Persons showing a much less extensive area affected, often a single patch, have been conveniently called Spotlings and such are not uncommon in Nyasaland. It is to be noted that the area or areas affected tend to be the same in different cases. In Piebalds the belly and chest are involved and often associated with a flare on the scalp and "garter" or "stocking" markings. In Spotlings this arrangement and extent may be wanting. The various members of the Nyasaland family will be seen to present intermediate forms. This distinction into two groups is warranted by the fact that in a number of cases where the affection is inherited the type is preserved.

The resemblance of the Nyasaland Piebald family to Bishop Harman's family is worthy of note, and it has been suggested that such cases of human piebaldism 


\section{Anomalies of Pigmentation among Natives of Nyasaland}

"are intensified representations of a light-bellied quadruped, that we have to deal with a case of palaeogenic inheritance," a subject associated with the name of Sir J. Hutchinson.

It will be found that I have set apart the Spotlings in which the penis only is affected as they form a special group owing to their great definition and owing to the little attention that has been paid to them.

I have pointed out, as will be seen later, that the pathognomic feature is the very light "pink" colour of the affected areas and their sharp margins.

My own working classification, therefore, is :

Complete (I) White skin, straw coloured hair, liquid blue iris with red reflex albinos. through pupil when examined with artificial light.

Spotted

albinos.

Partial

incomplete

Albinism.

Cases as above showing spotty pigmentation of the skin.

Xanthism.

(II) As above but the iris light yellow or hazel, photophobia and nystagmus not always present.

Incomplete

Albinism.

(III) Reddish brown hair and skin, light brown irides.

(IV) Skin light brown, not red; hair dirty light yellow, not brown; irides hazel.

Partial $\begin{cases}(V) & \text { Piebalds. } \\ (\mathrm{VI}) & \text { Spotlings. } \\ (\mathrm{VII}) & \text { Spotling of penis. }\end{cases}$

\section{Illustrations of Anomalies of Pigmentation.}

I shall now give notes of cases and discuss the group to which each belongs. Some cases of leucoderma are then described after which the relation of leucoderma with albinism is discussed and the theories as to pathogeny of the conditions brought forward.

The cases of albinism so far recorded from Nyasaland are as follows :

A. 1. From Kayuni's, N. Nyasa, by Dr Davey (p. 145 Monograph).

2. Charlie* of Chikulamayembe, N. Nyasa, by Dr Davey (p. 145 Monograph).

3, 4, and 5. Cases mentioned by Mrs Young of Karonga, N. Nyasa (p. 145 Monograph).

* I have seen this case and would add to the description already given that the scalp hair of a light straw colour grows down over the forehead to the eyebrows. The whole of the back and limbs are covered with semicurved very light straw-coloured hairs. Irides light grey blue with a light orange. coloured pattern. Pupil black in daylight. Teeth irregular, ill-formed, and carious. The pedigree is given as Fig. 7 of Plate XXI, II 2 aud II 4 were brothers, there are no other known albinotic members of the family. 
B. Cases seen and reported by myself and included in the Monograph on Albinism (to which pages and Figures in Pedigree Appendix refer):

1. Girl aged $4 \frac{1}{2}$ years, daughter of Dingo, Chiromo; Fig. 426.

2. Boy aged $2 \frac{1}{2}$ years at Zomba; p. $148 \mathrm{ftn}$.

3. Chesiwandiri of Maumi, S. Nyasa; Fig. 430, Plate Y (77).

4. Ng'ombe, S. Nyasa; p. 147, Fig. 427, Plate Y (80).

5. Child of Mtila, S. Nyasa; Fig. 431, Plate Y (79).

$\left.\begin{array}{l}\text { 6. Mbwerachaji } \\ \text { 7. Kantaye }\end{array}\right\}$ of Mvera, C. Angoniland; Fig. 428, Plate Z (84).

8. Old man of Nkoma, C. Angoniland

9. Old woman $\quad$ Fig. 432.

10. Young woman of Nkoma, C. Angoniland; Plate Y (78).

11. Soto of Angoniland; Fig. 433.

12. Sikumbiri of Blantyre; Fig. 434.

In the families of these cases 6 other cases occurred making a total of 18 .

13. The Piebald Family of Florence Bay; p. 250, Plates H (21), RR (147)-(150).

C. The following cases are now reported for the first time:
1. Alice.
8. Chikoya.
2. Saiti.
9. Nderemani.
3. John.
10. Mateuta.
4. Pingo.
11. Child of Annie.
5. Chibwana.
12. Moyichandi.
6. Tom.
13. Sawali.
7. Ali.

Case C1. Alice of Chikanji's Village, Dwangwa, Awemba Tribe. Pedigree, Plate XXI, Fig. 11.

The father and brother, a boy aged 6 years, are of average colour, the mother is rather light-skinned, café-au-lait. No relatives are known to be albinotic.

The albino (Plate XVIII (25)) is a child aged 8 months, she has a pinkish tinge to a very white skin, no vestige of pigment visible. Hair as nearly white as possible, not woolly on head. Irides a slaty blue with orange pigment network round the pupils. Ophthalmoscopic examination impossible. Red reflex not present in ordinary daylight. Lateral nystagmus and photophobia marked. There are some blisters and sores on neck and ankles, the result of sunburn; on body and limbs fine white downy hairs present; a small umbilical hernia present. 


\section{Anomalies of Pigmentation among Natives of Nyasaland}

This child, who presents complete albinism of the skin and hair, shows the peripupillary orange-coloured network, but no trace of brown pigment in the iris. At the present time, in the absence of any opportunity for making a microscopical examination of irides, showing this condition, I am a little doubtful how such cases should be classed. I think it is quite possible that this colour network is not due to granular pigment at all, but is caused by diffuse pigment such as is found in many specimens of red and golden hair, as will be mentioned later. This child is therefore provisionally placed in Class I.

Case C2. Saiti of Zomba. March, 1910. See Pedigree, Plate XXI, Fig. 1.

The maternal grandmother is said to have been a light-skinned native (I 2).

The mother's skin colour is light brown; Bwanali (III 6) and William (III 5) are dark brown; the first four children are dead and other members of the family were said to be of average colour, a dark brown. Saiti (III 7 on Plate XXI), aged seven, is practically the same colour as the back of the hand (not sunburnt) of a fair European, there are some blisters on the shoulders and arms but no freckles; skin thickened in places. The body and limbs are covered with fine whitish yellow hairs. Hair of head a dirty straw colour; eyebrows and lashes thick and much curled. Eyes; lateral nystagmus present, day-blindness marked, irides bluish-grey, with a faint yellow pigment pattern; pupils black. With ophthalmoscopic mirror a red reflex shows through the pupil, but not through the iris. Fundus a light pink colour, possibly a little lighter than in the average European. Teeth very bad. Abdomen prominent, small umbilical hernia present.

This boy is a very characteristic case of Class I, but shows the orange colouration in iris.

The frequency with which albinos have body hair and also bad teeth will be mentioned later. The red reflex was here obtained and the fundus, though found to be even paler than in an average European, still contained enough pigment to prevent the choroidal vessels being seen.

Case C 3. John of Mwandanas near Piupiu Hill, Zomba. January 6th, 1911. Mother and Father Anguru tribe. Pedigree, Plate XXI, Fig. 5.

With the exception of the first child, which is said to have been white, all the other members of the family are known to have been averagely dark-skinned natives. An elder brother (III 3) was seen and found of average colour.

John (Plate XIX (28)), aged 6 years, a complete albino. Skin colour that of a fair-skinned European; in places harsh and dry, smooth, with cracking and some blisters from sunburn. On the lower part of the abdomen, especially on the outer surfaces in front and on adjacent surfaces of thighs, numerous warts are present, mostly small, only slightly raised, and rather flat-topped. Others are larger, as is one situated over each clavicle, there are also a few which are filiform in character. They appear brownish in colour. The body and limbs are covered 
with light flaxen hairs semicurved, which, on microscopical examination, were found to contain no pigment granules. The hair on the head is very light flaxen colour, whisker areas covered with curved hairs. Eyelashes a golden brown colour, microscopically, no granular pigment in hairs*. Eyes: vision good in moderate light and pupils black, nystagmus present, red reflex present with artificial illumination. Irides, peripherally slaty-blue, round the pupil a light brown. The tongue has a bifid extremity. Teeth: two upper front incisors large, with serrated edges; all the front teeth above are spaced.

The child presents a fairly typical appearance of Class I save for the partial pigmentation of the irides, and on this account it must be considered as an intermediate between I and II. I am not sure whether the presence of the warts is of any significance; as far as I know, they have not been previously reported as specially associated with albinism. Note character of tongue and teeth.

Case C 4. Pingo of Chitalu, Liwonde, seen Zomba 18th August, 1910. Pedigree, Plate XXI, Fig. 2.

The parents, aunts and uncles of this case (II 3 ) and remoter members of the farnily are said to have been ordinarily dark-skinned natives. A cousin, a child of a maternal aunt, now dead, is stated to have been an albino. The eldest (II 1) of the family, of which Pingo is the second born, was albino, but is now dead; one other brother and three sisters normally black. Pingo is married to a normally dark native woman, who has had three children by him, all living and all dark.

Pingo (see Plate XIX (26) and (27)) is a man of 25 years of age. The skin of that part of the body covered by the loin-cloth is still very white, resembling the white skin of a European, and is soft and unaltered. The rest of the body shows changes in the skin of varying degree, the skin of legs being less affected than elsewhere; it is rough, harsh, scaly, cracked and creased with sunburns and superficial ulcerations; the skin is badly kept and dirty. There is hair all over the body and limbs, of a light straw colour; eyelashes, thick but ill-formed, are of a rather dark yellow colour.

Scattered over chest, abdomen, back, arms and neck, and also on the face are a number of areas from one third to one and a quarter inches in diameter, exhibiting a series of changes, giving the appearance of being of the nature of a pigmented atrophy; pari passu with the colouration, which commences as a light yellow colour, there is apparently an atrophy of skin substance, the final result being a black depressed spot, irregular in outline and with a brownish tinge at the edges, thrown into relief by the pinkish dirty white colour of the rest of the skin. Hair, a dirty straw colour, thick. Irides, a light opaque brown; lateral nystagmus present, but little photophobia. Pupils in daylight black. With artificial light, a red reflex is obtained, the fundus appearing a lightish red.

* The microscopical preparations of hairs in all cases referred to were made by Miss E. Y. Thomson, of the Biometric Laboratory, with the kind permission of Professor Karl Pearson.

Biometrika Ix 


\section{Anomalies of Pigmentation among Natives of Nyasaland}

When he smiles the subject has a retracted everted upper lip with fold of mucous membrane showing beneath it; the upper lip has a central linear depression instead of being pointed.

In reporting the case of Ng'ombe (B 4) it was pointed out that pigment spots hardly occurred apart from pitting and that the pitting might be the result of ulceration with scarring. In the present case, however, no history of such loss of substance could be elicited, yet a similar condition obtained. Both these cases are adults, whereas my other cases of spotted albinism are children in whom the pigmented areas are not depressed. Will these children develop depressed areas? I think they very possibly will. I believe that localised changes in the skin occur and cause the depressed areas, the pigmentation occurring before or at the same time, but whereas the pigmentation is visible in childhood the early results of depression are not seen. The irides of this man are a light brown, that is to say, more pigmented than in Ng'ombe, who only had an orange peri-pupillary ring. 'This case is included in Class II, though the iris colour makes it an intermediate type. A portion of skin including in its centre one of the pigmented spots was excised from the arm of this case and preserved*. Vertical sections were cut and examined microscopically stained and unstained and except for the complete absence of pigment granules the leucotic skin as a whole appeared in no way to depart from the normal. The several layers of the epidermis were not very thick, the dermal papillae and processes of epidermis between them being little developed but regular.

The structure of the skin at the site of the pigmented spot (freckle?) differed, however, very considerably. Here the dermal papillae are irregularly prolonged towards the surface so that the epidermal processes appear much longer but the rest of the epidermis thinner. The condition might be considered to resemble a wart which was "in" the skin and not "raised" above the surface.

Pigment granules were seen to occur in all the layers of the epidermis, most numerous in the cells of the downward processes of the epidermis, especially in the basal layer of these cells, which envelop the dermal papillae. They were seen to be more abundant in the peripheral parts of the cells and most densely packed at the deeper poles of the cells.

The granules were of a brown colour and where massed, appear as a homogeneous black mass.

In the subjacent dermis some cells were seen to contain pigment granules, they were few in number and the number of contained granules was small. Passing from the middle of the pigment patch where the aggregation of granules was greatest, they diminish in number as the periphery is reached. The diminution in the amount of pigment was seen to be gradual to one side of the section, the gradation taking place over several millimetres with some isolated

* See Plate XVII (21) and (22) for microphotographs of albinotic skin and "freckle." 
masses of cells containing granules beyond. To the other side of the section, the transition is accomplished in $0.2 \mathrm{~mm}$. This particular pigmented spot of skin was but very slightly depressed below the general skin surface, and though it is but a single observation I think the changes described would probably be found in all examples of the condition.

This is I believe the first time a "freckle" from a negro albino has been submitted to microscopical examination and it would be unwise to draw conclusions from this single observation.

Case C 5. Chibwana of Chikala. July, 1910. Pedigree, Plate XXI, Fig. 4.

Mother and father and two brothers and a sister all normally dark-skinned. The maternal great-grandmother had said there was an albino in the family ancestry.

Chibwana (see Plate XVIII (24)), a boy aged $4 \frac{1}{2}$ years (1910), has a dry cracked skin the same colour as a fair European; pigmented patches are gradually appearing on the face, also but less marked on chest and back and less still on the limbs. These patches are irregular in outline, black or dark brown in the centre, and a lighter brown at the periphery, but they are not depressed. Hair on head reaches to eyebrows, there is hair also on the cheeks, back, arms and legs, with little on chest, semicurved and white; on microscopical examination, it is found to be devoid of granular pigment. Eyelashes long and curled, of slightly yellower tint than hair on scalp. Irides, olive green with buff yellow pigment ring round periphery; pupil, not quite circular in outline, appears black in daylight. Lateral nystagmus present. On ophthalmoscopic examination a red reflex is obtained through the pupil, none through iris; fundus pink as in European.

I think in this case we see an early stage of the condition found in Pingo, which may progress until a condition similar to $\mathrm{Ng}$ 'ombe is reached.

Case C6. Tom of Chifira's Village, Bandawe, W. Nyasa. Pedigree, Plate XXI, Fig. 8.

The mother and father, former dead, were both of average colour. No history of albinism in the more remote ancestry. The first three children were albinos but were killed at birth according to custom among the Atonga. The fourth child was allowed to live owing to more civilised ideas of the chief, but died at the age of 15 years.

Tom, the last born, a boy aged 14 years (1909) is mentioned in the Monogruph and a photograph by Dr Robertson there reproduced (Plate PP (142)), but the history of the case is not given*. The skin of non-exposed parts is a pinkish white colour, elsewhere it shows sun-tanning and also a considerable degree of spotty pigmentation, the colour being not a brown to black, as seen in other cases, but a golden yellow like ordinary freckling in a European. Irides a light hazel

* [Given as Fig. 648 in Part IV of the Monograph. Dr Robertson states that there were two normal siblings and does not mention the dead albinos. ED.]

44-2 


\section{Anomalies of Pigmentation among Natives of Nyasaland}

brown. Photophobia and lateral nystagmus present. Dull red reflex present with artificial light. Vision very fair. No hair on body. Hair very white as opposed to the usual light straw colour; microscopical examination showed it to be without pigment.

The lad, though one of the lightest haired cases I have seen, had hazel irides, though, be it noted, as nystagmus and photophobia were marked, he would be placed in Class II, but owing to his spots, he is considered in Class I $a$. The spots of pigmentation present, however, do not approach in colour those on the younger boy Chibwana. Tom lived near a mission station, and I think may have worn more coverings than the other cases, who wore only a loin-cloth. This series of five albinotic siblings, all the children born, is a remarkable example of albinism in a family.

Case C7. Ali of Mwaimba, near Mvera, S. Nyasa; Yao; male, aged 16 years.

Three elder brothers, one younger, and one younger sister, mother and father all very dark. No more remote members of the family known to have been albinotic. The skin colour of the subject is a light "warm" café-au-lait. He is covered with fine golden hairs all over the body; hair of scalp, face, axillae and pubes a dirty straw colour. Irides a light reddish brown. Nystagmus present. Pupils black. Using an ophthalmoscope in a dark chamber, a red glow through pupil is obtained, but none through the iris. The optic papilla appears normal. The fundus reflects a red glow, a little lighter than that of a European; choroidal pigment is almost completely absent, allowing the choroidal vascular network to be completely visible, the small amount of pigment being collected into small deposits lying between the vessels.

The salient features of this case are a skin and eye colour which would cause me to consider it one of Xanthism, the hair also is rather dark for Classes I or II, but, on the other hand, the fundus is found to have less pigment in it than most other cases. He must therefore be considered to be an intermediate form presenting affinities with Class II and Class III. He has hairs all over the body, which I look upon as a condition very commonly associated with albinism.

This case I consider an important one in linking up the several types.

Case C 8. Chikoya of Mulowi, W. Nyasa. November, 1909. Pedigree, Plate XXI, Fig. 6.

Chikoya, a man of 25 years of age, is stated to have been, as a child, quite white, but has gradually darkened to present colour, of dark sunburn in a European; skin fine, not thickened nor cracked. Fine golden hairs are present on the arms, legs and shoulders; there is a light yellow golden moustache and beard; the hair of the scalp is a dark brown colour, as is also the pubic hair, but on microscopical examination it is found to contain only diffuse pigment and no granules. Hair said not to have darkened with age. Irides a light hazel; no photophobia; no nystagmus, vision good. 
In this man we see a case to be placed in Class IV, a group characterised by light brown skin colour (not red), in adult life, with nearly always a history of darkening with age; the irides are hazel, the hair, though it is a dark brown colour, contains no pigment granules.

\section{Case C9. Nderemani of Namalwere Village, Fort Maguire.}

This man, aged 25 years, was seen in Zomba in 1911 when returning from work on the South African mines.

Skin a rich "warm" brown colour; hair a rich red brown hue; axillary hair a dark brown; there are a few golden coloured hairs on the body and limbs. Irides, dark hazel; no nystagmus; vision good. There is a small umbilical hernia present. He says he has darkened with age and more rapidly since going to the mines than before.

This is a typical case of Xanthism, Class III. The hair, on microscopical examination, was found to contain few pigment granules, but a considerable amount of diffused pigment.

Case C10. Mateuta of Chiri, W. Nyasa.

Father of average colour. Mother states that she used to be "white" when a child; at the present time her skin tint is a light brown; irides hazel; hair black.

Mateuta, a child aged 2 years; skin colour a very light brown, face of lighter tint than body; irides greenish hazel, no nystagmus; hair light brown yellow with red glint in it; eyelashes and brows of a lighter shade; no hair on body. As an infant, is said to have been nearly "white." Vision apparently good. Mother and child constitute, I think, a short series, showing a progressive pigmentation, of value to the general subject.

Their histories show them to have possessed at birth a white, or almost white skin, which has become pigmented with age; the child's skin has not yet reached the degree of pigmentation of the mother's. The child's hair is a light brownish yellow, which is becoming darker; whether it will actually become black remains to be seen, but I expect it will. The same is true of the irides. The mother's are hazel, the child's are greenish hazel, strongly suggesting that increase of pigmentation is in process of taking place.

Case C11. The child of Annie and Annausu of Nkumbira, Nkata Bay. Pedigree, Plate XXI, Fig. 12.

All relatives dark; no other cases of albinism in family. The child (II 12) aged 8 years, is stated when born to have been almost white and to have darkened since; the same is said to be true of the hair. The face is a very light sallow earthy colour with dark freckles; skin of body a warmer tint of brown. Hair of scalp dark brown. A few fine downy hairs are seen on the body and limbs. Irides hazel; no nystagmus; vision good. 


\section{Anomalies of Pigmentation among Natives of Nyasaland}

This child, aged 8 years, can, I think, be taken with Mateuta and his mother and might be placed in the series as intermediate between the mother and her child. Together they seem to illustrate simply a delay in normal pigmentation, a phenomenon to which I do not think attention has been drawn, but one which must be taken into consideration when any attempt is made to theorise on the cause of albinism. Fig. 3.

Case C 12. Moyichandi of Sangano, Blantyre, Yao. Pedigree, Plate XXI,

Moyichandi, aged 18 years (II 5), is the brother of a case (B 12) Sikumbiri (II 6) previously reported in the Monograph, Fig. 434.

The skin is a light but "warm" reddish café-au-lait colour distinct from any normal native skin colour; irides hazel; no nystagmus. Hair light brown in colour, which on microscopical examination was found to contain fairly abundant granular pigment and a considerable amount of red brown diffuse pigment.

Sikumbiri, a year younger than his brother, has a lighter tint of skin, not so red; the irides are light hazel and nystagmus is present; hair dirty light straw colour. Both have hair on body and limbs of a yellow colour. In these two brothers we see an excellent example of the connection between two grades of deficient pigmentation; the elder I should class immediately as a case of Xanthism, whereas his younger brother must be placed as an intermediate between Classes II and IV. See Plate XVIII, Fig. 23.

Case C 13. Sawali of Ntiya Village, Mlumbi, Zomba; Yao, 1911. Pedigree, Plate XXI, Fig. 9.

Sawali, II 1 (for photograph see Plate XII, 1 and 2) and his younger brother, II 2, aged 13 and 5 years respectively, of whom the elder one only was seen, are said to resemble one another. Sawali seen in January 1911; hair of scalp from light yellow to brown, fairer on neck and at the edges of the hairy scalp; eyebrows and lashes black, no hair on body, pubic hair black; no albinotic characters in the skin, i.e. the skin is of a slightly lighter tint than the average native, but well within the limits of normal. Irides medium brown; no nystagmus; vision good. Teeth,

all the incisors are serrated thus: (mons ) they have the appearance of having ill-developed enamel.

Seen again two months later. He had in the meantime cut his hair very short, almost shaved, and allowed it then to grow again; the soft less-curled hair on the temple is a mouse-brown colour, the newly grown, tightly curled wool of the scalp is of a yellow colour, becoming brown near the roots; scalp colour is the same as the skin. He states that he was born with a white skin which has darkened since.

Individual hairs were found to vary in colour; some very light golden hairs were found microscopically to contain a yellow diffused pigment with very fine 
granules in fairly large numbers; brown hairs contained brown diffused pigment and abundant granules; some light hairs contained comparatively few granules, fine and widely scattered. There are some spots of pigment-like freckles of dead black colour, a few on neck, chest and back. On ophthalmoscopical examination a slight dark grey red reflex is obtained through the pupil; the fundus is a dull red, rather lighter than in average native.

Cases of partial albinism in which the hair only is involved but completely must be of rare occurrence, and I know of no case among African natives; such a striking figure, if seen, would surely have been recorded.

Note should be taken of the character of the teeth and the presence of body hair. This case should be considered together with the last cases above mentioned.

\section{Piebalds and Spotlings.}

With the exception of the Florence Bay family referred to earlier in this paper no other cases of Piebaldism have been seen.

The following cases are examples of spotlings that I have come across in Nyasaland. In the first group mention is made of white tufts of hair: in the second, spotlings of the skin are described.

(A) Several cases of natives presenting congenital white tufts of hair have been seen; they resemble each other almost exactly in that the canities occurred in the form of a median-placed flare on the anterior half of the scalp more or less triangular in arrangement, base in front. There were generally also a few white hairs scattered over the rest of the topmost portion of the scalp.

One such case also presented right and left helical fistulae, a congenital anomaly of no significance in this country, as it occurs in about $4 \%$ of the population.

Salule, of Chitanji Village, Chiradzula, showed two small tufts of white hairs, one placed in the median line, the other a little to the right and behind it, at the summit of the scalp; the scalp beneath them was a little lighter in colour than the surrounding. This man states that he was born like this and that one of his brothers, but no other member of the family, is similarly affected. The white hairs submitted to microscopical examination were found to be devoid of pigment.

G., the wife of a private in the King's African Rifles, aged 25, was seen to have white hairs scattered over the scalp which were said to have been present since birth; she presented no other albinotic characters.

Chitesima was another example of this condition. Microscopical examination showed the white hairs to be devoid of pigment, granular or otherwise.

H., a girl, aged 6 years (1909), from a village on the Lake shore in West Nyasa, presented a curious and interesting condition exemplifying partially 


\section{Anomalies of Pigmentation among Natives of Nyasaland}

deficient pigmentation. The affected areas were the right side of the upper part of the face, two small patches on the same side of the neck and a patchy condition of the fingers. (See Plate XIII, Fig. 5.)

The area on the face was sharply limited along the mid-line of the nose and forehead. The two patches on the neck were at the anterior margin of the trapezius muscle over the mid-point of the clavicle. The mottled condition of the fingers rather resembled that seen in Ziemann's leucoderma.

The general skin colour was that of cake chocolate. The affected areas were the colour of bruised chocolate. In addition to the affection of the skin, a segment of the iris about one-sixth of the total iris in extent, with the base directed towards the right side, was of a light hazel colour, the remaining fivesixths being a dark brown, the same as the iris of the other side. The hairs of the scalp, eyebrows and eyelashes were normally black. The condition was noticed at birth, according to the mother's statement, and had not altered. The mother, father and brother of the subject were all normal, and no members of the family were known to have presented any pigmentary anomaly.

I., female, aged 5 (1909). Seen at Kondowe; she presented congenital anomalies of pigmentation in that there was absence of full colouration of the skin; the back of the right hand, with the inner three fingers, the palm, and the back of the right arm, the abdomen, groin, thigh and leg of the same side were the seat of patchy deficiencies of colour, with spots quite white or pinkish white to various shades of brown, resembling somewhat the condition seen in leprosy, or the non-leprous leucodermic affection of the skin of the hands described by Ziemann. The condition was stated to be congenital and not to have altered. No other members of the family were affected.

Daus, of Chimwai village, Dwangwa River, male, aged 11 years (1909). An area of skin on the cheek, as indicated in Fig. 6, Plate XIII, is of pinkish white colour resembling that of an albino; the area is smooth and on the same plane as the surrounding dark skin. The demarcation is abrupt, with no increase in pigmentation of the skin in the neighbourhoud. Over the albinotic patch and also more abundantly on the surrounding skin are distributed fine white short curved hairs, no other hair being present on the cheeks. A few white hairs are seen on the same side of the upper lip, and the middle portion of the eyelashes on the upper lid of the same side are white.

There is an area of skin just in front of the tragus of a lighter hue than the rest of the skin of the face, which is a rather dark brown black colour. Irides dark brown. History states that these anomalies of pigmentation were present at birth. They have enlarged with growth, but there has been no relative increase in size. No other members of the family known to be albinotic.

The girl "H." presents a condition of extraordinary interest. In the first place, I can put on record a case of congenital incomplete spotling albinism, that 
is to say, a case with small areas of skin, congenitally deficient in pigmentation, but not completely albinotic. Secondly, the case demonstrates, I believe, a previously unrecorded condition, a partial and incomplete albinism of the iris; it is noteworthy also that the condition only affects one side, in fact the area on the face is strictly limited to the one side by the mid-line of the nose. This case will be mentioned again later.

In speaking of the other two cases I am not quite so sure of my ground.

The girl "I." presents no definite pink area of skin, but a condition resembling very much that described as Ziemann's leucoderma. It is said to have been present at birth, and the similar condition of fingers in the girl "H." supports the probability of this statement being true. The history that the condition is not changing is against leucoderma and therefore, on the whole, I am inclined to include it as a case of spotting.

(B) The special group of partial albinos characterised by an affection of the glans penis must now be considered.

My attention having been drawn to the point, the condition was then sought for among a number of adult men aged from 20-50, and including circumcised and uncircumcised, those with a partly retracted prepuce and those with a long covering. More or less complete circumcision is practised among the Mohammedan Yaos, but not among other tribes.

At the outset one must recognise that, just as in Europeans so in natives of Africa, there is very considerable variation in colour of the glans penis and inner surface of the prepuce, colour conditions which are fairly comparable to those of the mucous membranes. Just as in Europeans, variations from a delicate pink to the colour of uncooked lean bacon, from almost white to a purple red, occur; a similar variability is seen in uncircumcised natives, but always in the darker hues, that is, the skin in this situation always contains some pigment.

Dr Stachan, quoted by Pearson, states that the glans penis beneath a phimosed prepuce is always red; I am not quite sure whether he wishes to infer that the skin is devoid of pigment or not, but certainly the latter condition is the truth.

In the circumcised, the glans is practically always of the same hue as the rest of the penis and scrotum, i.e. a darker tint than the general colouring of the body.

In the uncircumcised, as a rule, according to the extent of the natural uncovering of the glans so is the degree of pigmentation.

The portion of glans normally uncovered by a naturally partially retracted prepuce is often darkly pigmented, shading off to red as the corona is reached; sometimes the general colour is a dark lean bacon-red, it may be with a purplish hue; in others, the general colour of the glans is an opaque leaden white. In

Biometrika IX 
all these cases, however, all variations in colouration shade into one another, and it is evident pigment is present.

Those cases which I have considered as spotlings show areas of various extent, always of a "pink" colour, with sharply defined margins, this being the test of a departure from the normal, which I consider includes the variations in colour above mentioned.

The following is an analysis of nearly 400 adult males, between the ages of 20-50 years, being prisoners and soldiers, and therefore they can be considered as taken at random from various tribes.

379 Adult males examined with reference to colour of glans penis and prepuce.

(A) 122 Circumcised: All have completely black glans penis except two $(a$ and $b)$.

(a) Some spotty pinkish colour present at the seat of the operation cicatrix. (N.B. the circumcision was performed when subject was adult.)

(b) Chambveka, the general colour of the glans is a dark brown, but there is a light brown spot on the dorsum near the meatus.

(B) 259 Uncircumcised:

(1) Inner surface of prepuce and the whole of the glans penis dark brown or black

(2) There is a gradation of colour from the corona to the meatus and corresponding part of the inner surface of the prepuce from blue red, leaden or yellowish white to dark brown or black . . . . . . 100.

(3) Glans and inner surface of prepuce of a uniform colour, from a leaden white to a bacon-red . . . . . . . . . . . 75 .

(4) Glans and inner surface of prepuce of about the same colour as in a fair European, but at the free edge of the prepuce shading off into dark brown or black of the general skiu colour . . . . . 20

(5) As in (4), except that the lips of the meatus were dark brown 3.

In another case there was some deeper pigmentation about the frenum shading off into the surrounding colour; the skin colour was a dirty yellow brown, rather like that of a half-caste, with some freckling; hair black; irides dark brown.

(6) Spotlings

1.

From the above it will at once be seen that among the circumcised one may say no spotlings were found; case $(a)$ had some alteration in the neighbourhood of a scar and is of no import; $(b)$ had a condition which may be called leucoderma, or may be a congenital condition, and be called albinotic, but no history was forthcoming. 
Colour variations among the uncircumcised, $(1-5)$ came within the limits of normal variation as above described. The single case mentioned in (5) I look upon as really one of the intermediate cases towards albinism, a view strongly supported by the freckling.

To deal with cases under (6) in detail:

(a) Lijuni, aged 30, glans and inner surface of prepuce a very bright pink (considerably lighter in colour than in an uncircumcised European), bounded by a sharp line of demarcation at the junction of the inner and outer surface of the prepuce. There are a few white hairs in the mid-line of the beard and at the outer corners of the moustaches, but no other albinotic characters. See Plate XIV, Fig. 8.

(b) Erya, an Angoni, as in (a) but with an area of dark brown, involving the lips of the meatus, though covered by prepuce, thus differing from cases mentioned above (5).

(c) Matesi, an Atonga (see Plate XV, Fig. 11).

(d) Jim, ground colour of preputial-glans-skin of a reddish grey, albinotic area shown in Plate XV, Fig. 12. Skin colour a dark chocolate; irides dark brown; on the front of the abdomen there is a spotty condition, light and dark brown; there are a few freckles, one each on the right side of the abdomen, left chest and back.

(e) Chizizu, Yao (see Plate XV, Fig. 13), nothing else to remark.

$(f)$ Lief. Dark brown skin and irides (see Plate XV, Fig. 14).

(g) Chiwia. Besides the larger patches of albinotic skin on the glans, there is a spotty pigmentary change about the frenum (see Plate XVI, Fig. 15). The skin and irides were a dark brown colour, and there were some scattered grey hairs on the scalp. Man, aged 30 years.

(h) Chivia, Angoni, skin and irides dark brown (see Plate XVI, Fig. 16).

(i) Naamon (see Plate XVI, Fig. 17).

(j) Yohani. There is a patchy light and dark brown pigmentary change in the neighbourhood of the frenum.

(k) Magombo. Red pink ground colour of glans, etc. with leaden blue spot, as shown in Plate XVI, Fig. 18, skin colour a dark chocolate.

(l) Asani like (k), only spot is brown in colour; scrotum and penis black, skin colour light brown with large black freckles, one on each leg, and some on body and face.

(m) Mwenengwi. Tightly phimosed, but some spotty pink areas can be seen just on the inner surface of the foreskin.

A further case has since been seen. Binali, 1st K. A. Rifles, Zomba, 1912 (see Plate XIV, Fig. 9). 


\section{Anomalies of Pigmentation among Natives of Nyasaland}

Lijuni [(a) above] was circumcised by me on 5th April 1911. Fourteen months later he was again seen. Examination revealed a circular patch of pigmentation dark brown in colour involving the lips of the meatus and a small area round them, three-eighths of an inch in circumference; the remainder of the glans was of a light pink colour, totally devoid of pigment as at the time of circumcision. The prepuce was carefully preserved and transverse sections prepared and mounted unstained and stained with haematoxylin and ensin and by Van Gieson's method for microscopical examination. I may say at once that, with the exception of the deficiency of pigment granules, the whole structure of the albinotic areas of the skin appears normal. In the normally pigmented part of the prepuce the basal cells of the Malpighian layer are the most deeply pigmented, some of them being so full of dark brown granules as to appear almost black and homogeneous; this is most marked in the cells at the end of the deep processes of epithelium dipping down into the dermis and also in the cells lining the lower parts of the sides of these processes. Those cells less deeply placed are less pigmented, but all the cells, even the most superficial ones, of the stratum corneum contain some granules. The granules tend to be arranged round the periphery of the cells, especially at the distal end of the cells, giving a very characteristic appearance. In the subjacent dermis a few cells containing pigment granules are seen, small in number and not very heavily pigmented. The transition from the normal pigmentation to skin absolutely devoid of pigment is seen to occur in from 1 to 2 millimetres, that is to say, it is not absolutely sudden but the gradation is rapid. The diminution in the number of granules is practically proportional in all layers of the epidermis; in the dermis the loss appears possibly to be absolute before the same change is complete in the superjacent epidermis, and the cells lining the sides of the deep epidermal processes retain a greater number of granules than the cells at the more superficial and deeper parts: see Plate XVII (19) and (20).

Prolonged beyond the last cells containing granular pigment a band of yellowish brown diffuse colour is visible affecting a layer of cells two or three cells thick at the junction of the stratum corneum and stratum granulosum.

\section{Notes on Anomalies of Hair Pigmentation.}

Samples of hair were examined with results as follows:

Simbeleta and Nederi, a type of rather coarse hair, which is not very curly, recognised by the natives as turning white early in life. Microscopically white hairs were devoid of all pigment, a few brown hairs showed brown diffuse pigment, with densely packed granules, the black hairs being normally black and completely packed with black granules.

Mwana Ngala. Aged $2 \frac{1}{2}$ years, stated to have had yaws, and in consequence of this illness the hair at the sides of the head and temples is brownish in 
colour; microscopically there was a diffuse brown pigmentation and granular pigment was fairly abundant.

Another child showed the same changes under similar conditions.

Old female inmate of the Central Prison of an age when grey hairs have usually appeared; she was noticed, however, to have some brownish hairs, and others of a bright golden colour; the black and brown hairs were found to be tightly packed with black granular pigment-the golden hairs contained light yellow diffused pigment, but no granules.

Kause. An old female lunatic, presented the same hair characteristics, macroscopic and microscopic.

Three men were noticed with a certain number of red hairs in the moustache, comparable to the hairs in the moustache of a "red haired" European.

Yotam. Scalp hair black; skin a lightish brown, is said to have darkened with age; irides a dark hazel. Microscopically the red hairs contained a certain number of fine pigment granules, but also bright red diffuse pigment, black hairs absolute black, with granular pigment; some of the hairs were partially red and partially black, each part showing the corresponding condition mentioned above.

Pamandhe. Brown moustache hairs showed diffuse brown pigment and fairly plentiful black granules; black hairs and some particoloured hairs as in case above.

Chamveka. Light brown hairs were devoid of pigment granules, there were some particoloured hairs, which, with black hairs, answered to the description above.

Bandsman, 1st K. A. R. Hairs from dermoid cyst of forehead. Hairs spindleshaped, tapering at each end; brown diffuse and granular pigment present, but not equal to full pigmentation.

\section{Case of Leucoderma.}

I now describe a case which clinically is one of leucoderma. It is the only case showing leucodermic areas of any extent that I have met with, from which I think I may infer with reason that leucoderma is rare among these natives save in its minor manifestations.

This case corresponds very well with a text-book description of the disease-a symmetrical and progressive condition associated with hyperpigmentation. Points of interest are that the patient is sure the hyperpigmentation has occurred on sites previously depigmented. The hairs on affected parts of the skin which are naturally hairy are black. Black hairs are also seen to occur on leucotic areas on non-hairy portions of the skin.

Ouda, of Chechiwere's, male, aet. 15 years, Zomba, November 14th, 1910. Disease started 3 years ago; he was seen at that time by my native Hospital Assistant who vouches for this date. He has never had yaws. The disease 


\section{Anomalies of Pigmentation among Natives of Nyasaland}

commenced as a very small patch on the right shoulder which has never spread. Now spots are seen on the body, face and limbs (Plate XII, Fig. 3).

$\mathrm{He}$ states that a patch appears very quickly, in a few days reaching its maximum size and that the extremities are the last to become involved. At the present time the middle two-thirds of the red margin of the lower lip are affected, there is a patch on the right side of the filtrum of the upper lip, some small areas over the left shoulder, three patches the size of a half-penny over the upper part of sternum, a few points over the chest and abdomen in front and on back; the arms from the elbows downwards are the seat of large patches; the wrists, thumbs, dorsum and palm of hands and fingers also show patchy depigmentation; patches on the left knee, the dorsum of the feet and toes, and over the ankles are also present.

These affected areas are of a pink colour as of a fair European skin; they are in some places a little crusted.

There is a lack of signs of slow depigmentation, that is, areas of all shades of dark brown to pink are absent. In association with some pink areas there is a surrounding hyperpigmentation; these the boy states were previously depigmented and pink. This phenomenon was well seen on the arms, the leucotic areas presenting black hairs as on unaffected skin. Affected areas over the manubrium sterni, though there is no hair on the surrounding normal skin, present hairs which are black. No one else in the family affected.

Under the name of "Melung" (Beta), Ziemann has described in the Archiv für Dermatologie und Syphilis, Bd. Lxxıv. S. 163-170, Wien und Leipzig, 1905, a skin disease among negroes on the West Coast of Africa "characterised by the appearance of round, oval or irregular shaped patches of a bright yellow red colour on the skin of the extensor and flexor surfaces of the hands and feet." Here in Nyasaland I have seen a number of cases which correspond more or less with the descriptions given by Ziemann, but there are several points of difference, and I am inclined to think that that observer has made too hard and fast limits for the type of leucoderma which he has described. He says, "The predominant colour of the affected areas is of a whitish tinge and the general aspect may be compared to that of extensive superficial burns which have healed without the formation of granulation tissue. The disease begins at the age of from 10-15 years; its course is symmetrical, either attacking the hands first and then the feet or the feet first and the hands afterwards, or both at the same time. The progress of the disease is extremely chronic." He further notes that never more than four-fifths of the surface of the hands or feet are affected with pigment atrophy. The flexor surfaces are more extensively involved than the extensor, the pigment atrophy is practically confined to the hands and feet, only further slight extensions occur after 10-20 years and there is gradual loss of pigment in the hairs situated in affected regions. Sensibility to touch, temperature, and pain and muscle sense are unimpaired; the sweat glands are normal; 
the electrical reactions of the affected limbs are normal and there is no evidence of disease of the nervous, blood or excretory systems.

As far as I am aware no mention has been made of the disease occurring elsewhere than among West African negroes, I therefore give some details of a few cases met with by myself.

Chisfufu. Male, aged about 36. The headman of a village near Zomba. Subject states that the disease commenced on the left side of the chest when he was 6 years of age, then both hands and arms were affected followed immediately by the legs, and it has been slowly progressive till the present time. When seen there was a spotty hyperpigmentation on the front of the chest (see Plate XX, Fig. 29) only two areas being actually of a pink hue, the same condition is seen on the back; the changes on the hands and feet are typical. The depigmentation seems to have occurred in circular areas so that on fusion the margin assumes a scalloped form.

X. Female, aged 50. States that her affection only commenced 2 years ago. On examination the left hand and wrist are found to present the typical features of the disease, and though of only 2 years' duration it is as marked as in cases of 20 years' standing. On the palm of the right hand there are some spots $\frac{1}{3}^{\prime \prime}$ in diameter of slight hyperpigmentation, signs of the commencement of the disease in this extremity.

Binti Masua. Female, aged 30, of Mponda, wife of Mwini Dowa, private 1st King's African Rifles.

She states that she had yaws when aged 8 and that the leucoderma appeared at that time, and has remained of about the same extent since childbood. On examination there are seen some black areas on the arms, apparently the hyperpigmented scars of old yaws. She has a Dupuytren's contracture affecting both little fingers, the first interphalangeal joints of both hands are thickened, and the fingers show a slight degree of ulnar deflection. The affection is less advanced in the left hand than the right. In the former the depigmentation only affects the palm, while on the right side, the dorsum and fingers are also involved. Hyperpigmentation is present as a band round the wrist, along either border of each hand across the bases of the phalanges and on the back of the first fingers and sides of the middle fingers.

Licheta. Male, aged 50, inmate of the Central Prison, Zomba, an Angoni of Dedza.

The disease is said to have commenced at the age of 17 on the palmar surfaces of the wrists, since when it has very slowly spread till the present time.

The affected areas include both surfaces of the hands and wrists, and extends two inches on to the forearm; the depigmentation is patchy in character; where the process has been most intense the skin is of a yellowish pink colour. Circular areas are seen showing all grades of depigmentation as evidenced by the different 
shades of brown present. Round the areas in which the change has taken place there is hyperpigmentation more or less marked, in some areas the skin being absolutely black. There is a worm-eaten appearance on the palms of the hands which the man states is the result of yaws in boyhood. There is also compound ganglion affecting both wrists. The photograph (Plate XIV, Fig. 10) illustrates rather poorly these features.

Mundana. Male, aged 40, of Chikumbo, Mlanje, Makua.

Patient states that the affection of his hands and feet was present at birth, and has not altered since. This I think is very doubtful and probably one may infer that the disease began in very early childhood, and has not progressed of late years. He says he has not suffered from yaws. Both hands and feet are affected, the former to a small degree and the feet still less, so that it is hardly noticeable in the latter.

There are only two or three small areas actually pink, for the most part the colouration is patchy and of various shades of brown to orange. The process has involved the hands and fingers, the wristband area and the dorsum of the foot and toes on both sides.

There is a hyperkeratosis of the palms of the hands and of the skin of the extensor surfaces of the interphalangeal joints. The palms of the hands also present a worm-eaten appearance with the formation of little pits. There is likewise heaping-up of epidermis with cracking at the flexures on the palms. The hairs on the extensor surfaces of the fingers have fallen out, leaving little pits.

Y. Male, aged 40. A Swahili from Zanzibar, Range Capitao, Zomba. The hands only are involved, but in a perfectly typical way. The disease is stated to have commenced when the subject was a small boy.

Other cases have been seen but of them no notes have been kept. In discussing the relation of these cases to ordinary leucoderma it must be remembered that natives are seen with a similar patchy speckled depigmentation process affecting the skin of other parts than the hands and feet. Thus I have seen a condition along the middle line of the back or in the middle of the chest on several occasions. In the case of a girl I., aged 10 years, mentioned above, it was associated with similar speckled condition of the fingers, and was said to have been present at birth. Chisfufu, as will be seen by a glance at the sketch on Plate XX, not only had a typical affection of the hands and feet but the process also involved the trunk, all four limbs and the lips.

While it is true that there is a large number of cases of an "imperfect" leucoderma corresponding more or less to the description given by Ziemann, I find that there are many others in which the process is wider in its distribution and which are therefore connecting links between the type described by Ziemann and ordinary leucoderma. Even in such cases of long standing the areas involved are of small extent, and it is but seldom that one would see a portion of skin of 
any size reduced to the pink colour such as is seen in ordinary cases of leucoderma i n natives.

It is however difficult to see where to draw limits around any particular type, though I must agree with Ziemann in setting apart the hand and foot type as a fairly definite variety. I agree with him in thinking that the disease does often start during youth, but I am not convinced that it always does so. Again it is nearly always symmetrical after it has been existent for some time, but not always so at the beginning. I believe that in most cases the hands are affected before the feet, and though in the majority of cases the progress is very slow, yet in some it may run a more rapid course for a time, and then become stationary.

I have certainly never seen more than four-fifths of the hands or feet affected. The flexor surfaces are more extensively involved than the extensor, but the change is by no means so commonly limited to the hands and feet as Ziemann makes out. I would say that it is more usual for some two or three inches of the fore-arm to be involved as well. I should be inclined to lay more stress on the character of the colour changes. Practically in all my cases there was hyperpigmentation to be seen in areas of skin adjoining those in which loss of colour had taken place. This was generally most marked as a black band around the wrist, but was seen elsewhere.

The loss of pigment as above mentioned would appear to take place at a number of points more or less at the same or at different times, so that round areas are produced showing varying degrees of loss of colour which may coalesce with the formation of larger areas with scalloped margins. Often in the middle of such a depigmented area, one that may have been reduced to whitish-pink or yellowish orange colour, small spots of more deeply pigmented skin may be seen to remain.

Ziemann has compared the appearance to the result of extensive superficial burns which have healed without the formation of granulation tissue. Such a description I do not consider good, as under those circumstances the skin is essentially pink and never of the orange yellow or yellow white colour characteristic of the affection under consideration. Again, the laying down of pigment after burns occurs at points partly separated from one another, which appear very dark indeed, and do not resemble the darkly pigmented patches seen in this disease.

Attention might again be drawn to the fact that the history of yaws was obtained in several cases and a few show evidence of lesions almost certainly the result of framboesia, I refer to the pitted appearance of the hand and hyperkeratosis. The loss of the hair from the digits in one case should also be noted as possible evidence of a trophic element in the etiology of the affection.

Below are short notes of cases of melanodermia of congenital origin as far as their histories could be elicited.

Biometrika Ix 


\section{Anomalies of Pigmentation among Natives of Nyasaland}

Female, aged 17, Zomba, 1910. An area of absolute black skin is seen on the right side of the neck extending over the clavicle. No other affection of pigmentation noted.

Bimba, male, adult, Zomba, 1910. Patch of black skin on the dorsum of the left foot, over the heads of the first and second metatarsal bones.

Talo, adult, male, 1st K. A. Rifles, Zomba, 1911. A black patch of skin under the right nipple.

Mainana, adult, male. Below right axilla there is an area of skin $4-5$ inches square in extent of a dead black colour.

\section{Conclusions.}

The cases I have cited go to illustrate the following facts :

1. Albinism is common among the natives of Nyasaland.

2. It is a family affection and often directly hereditary.

3. Varying grades of albinism are met with in the same family.

4. Almost every degree of albinism is met with.

5. The degree may vary with age.

6. A secondary laying down of pigment in the albinotic skin in spots is a not uncommon feature.

7. Albinism is very generally associated with an unusual development of the lanugo hairs and less commonly with mal-development of the teeth.

8. Piebalds are comparatively rare.

9. Spotlings are less rare.

10. There is a very definite class in which the spotling condition affects the penis only.

11. Widely distributed leucoderma is uncommon.

12. A localised form resembling that described by Ziemann is common, but intermediate cases between this form and a more generalised form are seen.

13. Some congenital cases of spotlings resemble exactly some cases of leucoderma.

The grades of albinism in their relation to one another may be diagrammatically represented; this arrangement has however no pretence to mathematical precision.

In the same way the relations of the various conditions characterised by partial albinotic characters may be roughly sbown. 


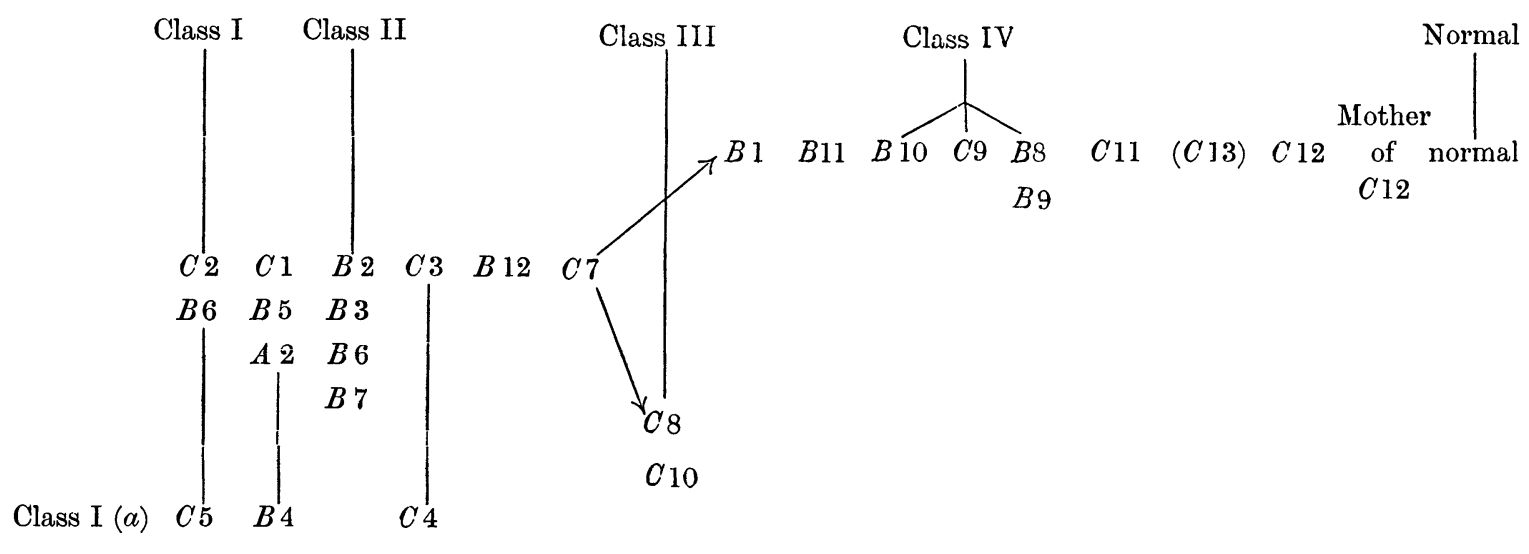

\section{Partial Albinism}

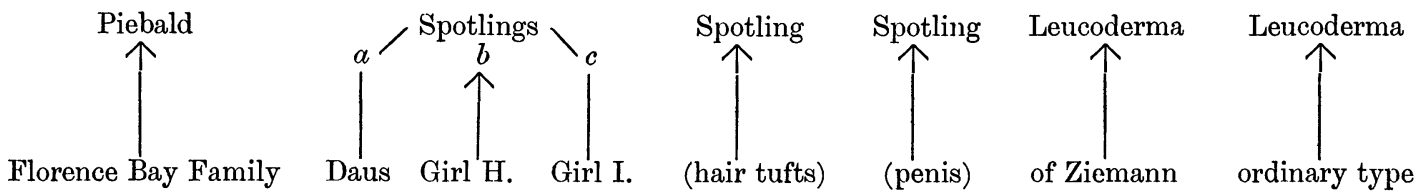

Coming to a more general discussion of the subject, among facts which have to be taken into consideration the following mentioned by Pearson are of great importance. Leucoderma may occur very early in life and become stationary. Pearson says "the possibility in Leucoderma of very early development followed by a stationary condition, and the fact that babies only gradually develop skin pigment so that congenital unpigmented areas may not be at once noticed, render it not so easy to distinguish partial albinism from stationary leucoderma in a European." Concentration of pigment in the neighbourhood of leucotic patches has been laid stress on as a feature of leucoderma, but it is not invariable. Symmetry and progressiveness and the combination of excess and deficiency are held by Crocker to be the characteristics of leucoderma, but as Pearson says "there can be little doubt that...leucoderma ceases to be progressive in some cases and that in such cases...the increased pigmentation at the borders is wanting." Further the symmetry "may be by no means marked" and the distribution of patches in undoubtedly congenital cases of leucosis may show a considerable degree of symmetry. Evidence of recovery of pigmentation in leucodermic patches is not wanting.

Leucoderma has further been shown to be inherited, and a case due to Dr Joseph Jones has been published in which inherited leucoderma seems "to have culminated in albinism." There thus appears to be no criterion by which any case can be judged to be one of leucoderma or of partial albinism, and the history may yield the only facts of value. For these reasons, any hypothesis to explain albinism must explain at the same time the facts about leucoderma as they are known. 


\section{Anomalies of Pigmentation among Natives of Nyasaland}

In dealing with the pathogeny of the condition I follow largely Pearson in his presentation of various theories. The normal formation of skin-pigment is a question around which much conflicting opinion has grown. The site of the formation of the pigment has been variously supposed to be in cells belonging to any or all of the primary layers, endo-, meso- and ecto-derm.

Special cells have been described as acting as carriers of pigment from one layer to another and called in consequence chromatophores (Kölliker, Simon, Kerbert, Ehrmann); Ehrmann later considered these cells to be actually the producers of the pigment, and calls them chromatoblasts or melanoblasts. Meirowski's summing up of Ehrmann's views quoted by Pearson is as follows:-

(1) The production of pigment occurs in special cells, the melanoblasts, which are not identical with mesodermal or epidermal cells.

(2) The melanoblasts are products of the middle germ layer, which in part further develop there, grow into the epidermis, and there have an independent cell existence.

(3) The material which is converted into melanotic pigment comes from the blood and is haemoglobin. Haemoglobin is converted into melanotic pigment by the vital processes of the melanoblasts.

(4) Extra-cellular creation of melanotic pigment is not yet demonstrated. True melanotic pigment only occurs in an extra-cellular form by the break-up of pigmented cells.

(5) The transfer of pigment occurs by aid of protoplasmic flow along protoplasmic threads, which connect the melanoblasts with the epithelial cells. For this reason this theory is not an "Einschleppungstheorie" but an "Einströmungstheorie."

(6) Pigment is, at least shortly after its production, a body dissolved in a highly fluid colourless substance.

Unna believes that the pigment granules formed according to Ehrmann's hypothesis pass by way of the lymph stream to the epithelium.

Cohn holds that free pigment certainly exists outside the cells.

Schwalbe believes that epidermal and dermal cells can each produce granular pigment as a result of their individual activity, drawing upon the same source, though independently; he believes that: (i) a pigmentation of the cutis can occur with completely unpigmented epidermis and hair, and (ii) a pure epithelial pigmentation can occur without trace of pigment in the underlying mesoderm. He rejects the chromatophore theory and considers these cells to be transformed epithelial cells.

Kaposi also criticises Ehrmann's views to show that a haemoglobin origin for melanin is untenable. More recently other observers (Meirowsky, etc.) have come to the conclusion that epidermis and cutis pigment can arise independently, and 
the melanoblasts of one and the other are independent structures. The nature of melanin has been investigated by a few observers. Hopkins and Cole have isolated a substance as a product of tryptic digestion of proteid which may be the mother substance of the proteinochromes skatol, pyridine and tyrosine. Tyrosine by the action of a ferment can be changed into a substance resembling melanin.

This ferment tyrosinase has lately been found in a variety of species, plants and animals, including newborn rabbits, rats and guinea-pigs.

The above notes on melanin are gleaned from Pearson's observations on Von Furth's summary.

Dyson has recently shown, by means of the bichromate-haematoxylin method of Lorrain Smith and Mair, that pigment is always formed as part of a complex granule which contains lipoid substance. These granules are present constantly in the basal epithelial cells, and are formed there under the influence of the nucleus as a part of the normal metabolism of the cell. The pigment is in origin a lipochrome, the melanin being the chromatic proteid portion after separation from the complex lipoid granule. He found no evidence of pigment formation in the cutis, but showed sections which illustrated the passage of lipoid substances from the epidermis into the cutis along lymphatic channels.

It appears therefore that our knowledge on melanin and its production so far points to the following conclusions :

(1) Melanin is not a direct (and probably not an indirect) product of haemoglobin.

(2) It is the product of splitting of a complex lipoid substance possibly as the result of a ferment action, akin to the formation of pigment from tyrosin by tyrosinase.

(3) The complex granules containing the lipoid substance are produced as the result of the metabolic activity of the individual cells of the epiderm.

(4) The presence of melanin is responsible for skin pigmentation.

(5) Melanin in the cutis is probably derived from the epidermis.

This is as far as knowledge goes at present with regard to melanin. How can we explain its more or less complete absence in albinism, etc.? Pearson surns up "when we consider the relative rareness of complete albinism, of the spotted or splashed condition and of Xanthism, their relatively frequent coincidence in the same stock suggests that these abnormal pigment conditions are not wholly independent, and that as a working hypothesis it is reasonable to suppose that complete albinism, partial albinism, incomplete albinism and Xanthism, all static forms of leucosis, are phases of the same process and are probably linked with leucoderma and possibly other forms of dynamic leucosis. By 'linked' we suggest that they mark the complete, incomplete, local or progressive failure of the same metabolic process, which may never start at all, never start in certain areas, or be imperfectly started, and again being started may fail to maintain itself; further 


\section{Anomalies of Pigmentation among Natives of Nyasaland}

that every variety of this failure may individually or collectively be associated with certain stocks, which may either show hereditary failure of one phase, of several, or exceptionally of all phases of pigment metabolism."

This hypothesis gives a masterly summing up of the position, warranted, I think, if only in the light of my own series of cases.

If we seek the cause in some inherited defect we might suppose that some pigment-controlling determinant by its absence causes failure of natural pigmentation. Its perfect or imperfect impotence may be a racial feature of certain forms of parental albinism. This impotence may be a racial feature of certain parental stocks or produced by some degenerating influence of the somatic on the germ cells of the individual parent such as must occur in the case of an inherited character arising in the parent as a "sport."

This absence of certain determinants does not carry us very far, for the question suggests itself: how do such determinants act on the normal body metabolism? It has been suggested that some ferment necessary for pigment formation such as tyrosinase is absent.

As Pearson says, "it must however be remembered, (i) that the absence of the ferment in the albino must correspond to some abnormality in the zygote and ultimately to some defect in one or both gametes. This defect can hardly be an absence of ferment. (ii) The materials for development are supplied in utero by the mother, who may be $(a)$ herself pigmented, and $(b)$ produce at the same time pigmented and unpigmented twins. It would appear that she is thus able to provide the ferment for one and not for the other offspring."

One might postulate ferment determinants. Pearson suggests "that the ultimate difference between the normally pigmented individual and the albino, will be found after all to be one of structure; the failure of the normal metabolic process is due to differential structure in the albino. If there be local absence of ferment it may possibly be that the structure does not permit of its reaching its destination," and mentions in support of this view that albinos may have a considerable amount of diffused pigment in their hair.

He also says that it would be difficult otherwise to understand how in cases of partial albinism the ferment should be confined to some portions of the skin and be wanting in others. Facts gleaned from my own observations which seem to have a direct bearing on some of these points I may here refer to. I should like first to mention some observations on the natural rate of pigmentation in African natives.

Pearson states that a black baby at birth almost resembles a white one in colour, and quotes Dr Strachan*. With all deference to Dr Strachan, I most

* [This does not seem adequately to represent the views of the authors of the Monograph, or of Dr Strachan. The reader is referred to pp. 120-124 of that work, where much of the literature on the subject is cited. The point involved is not the impossibility of distinguishing between a just born white and just born black baby, but to the fact that the black pigmentation except on the genitals and some other parts is relatively slightly developed at birth. ED.] 
certainly must differ from him and agree with Dr Pooley, also quoted, when he says that "in newborn babies (negroes) the skin being thinner, the pink of the blood vessels is much more clearly seen, but the skin has an ashy grey colour all the same, the black is there all the time"-a phenomenon which is clearly seen in the still-born and premature births. I do not besitate to say that a portion of skin of the new-born native of this country could be immediately distinguished from a portion derived from a new-born European child. To give an example, the infant of Private Jumbe, 1st K. A. R., seen immediately after birth, had a skin colour of a pinkish white with a dark café-au-lait tint about it, not the dead white as seen in other young albino children; hair of head rather straight and a dark brown in colour, body and limbs covered with very light fine hair of the lanugo type; irides a liquid steel blue. Darkening of the skin occurred rapidly; it was not noticeably light after three weeks, and in three months it was an ordinary "dark" coloured baby.

Specimens of hair from the head and body having the colour as above mentioned were taken a few days after birth. The hair from the scalp was seen to contain bright yellow diffused pigment, and a fair amount of brown granular pigment. The body hairs were very fine and undeveloped, and very fine granular pigment was present.

The pigmentation, then, of the skin (irides and hair) of the native of Central Africa is a progressive process; normally pigmentation is quite marked at birth and thereafter proceeds rapidly, but in a large number does not reach, so to speak, completion till the age of possibly 16 years. This I have noticed with three or four of my younger servants who during the six years they have been with me have darkened very materially.

This production of pigment as the result of metabolism in certain cells might be likened to the production of the salivary ferments by the salivary glands. The cells are there in the skin ready for their work in the foetus just as the cells of the salivary glands are, but the latter do not begin to produce their ferments till they are needed (for the digestion of certain foodstuffs); in the same way the skin of the young foetus is unpigmented, and it is only when pigment is about to be needed that it is formed. During the few days after birth there is a call for its rapid formation and it is produced.

The stimulus for this rapid formation is probably light rays or ultra-spectral rays acting indirectly by means of a ferment, though, now that pigmentation is a racial characteristic, the tendency for the process to start and go on is represented in the germ-plasm of the parents. This inherent tendency to produce pigment is borne out by the fact that the latter was present in the hairs removed from a dermoid cyst (vide supra).

That depth of pigmentation is conserved as the result of such a physical cause as light I have no doubt, as the following observation will serve to show. I held a medical inspection of the 1st Battalion of the King's African Rifles the day after 


\section{Anomalies of Pigmentation among Natives of Nyasaland}

part of the Battalion had returned from Somaliland. I was surprised to find when the Battalion as a whole stripped that the men who had been on foreign service were many shades darker than those who had remained in the Protectorate of Nyasaland. The Somali men were as black as any native I have ever seen, and by comparison the Nyasaland men looked like members of a yellow skinned race. The reason for this difference was that in Somaliland all fatigues had been done bared to the waist, while the men remaining in Nyasaland had not been without regimental clothing (khaki tunic or blue jersey) for years.

I obtained a similar result by keeping several turns of bandage round the chest of a native for eight weeks.

Again, I would refer to my observations on the skin colour of the penis. One may say that normally the ensheathed glans penis is not deeply pigmented; the pigmentation of the partially covered glans is proportional to the want of cover. The glans of a man who has been circumcised is invariably black. Therefore though always pigmented to some degree because skin pigmentation is a racial characteristic, the process is only completed as the result of exposure in the majority of cases. Special notice must be taken of the case of albinism of the penis; wherein, after circumcision at the age of 26 years, the skin of the glans, which was absolutely albinotic and would doubtless have remained so all the man's life had he not been subjected to operation, developed a spot of pigmentation a year later. How could this case be accounted for on the theory of structural defect*? It is a fact worthy of remark that the penis should be the commonest site to find a spotling albinism and that it should occur in close on $4 \%$ of 379 men taken at raudom; excluding the circumcised, it occurred in nearly $6 \%$.

In a large number of albinos we have seen there is a marked ability to form pigment (vide spotted albinos, and those of Class IV, who develop a certain amount of pigment in the skin but not in the hair and again those in whom pigmentation is only delayed, cases C11, C 12 Sawali) which does not appear to point to defective structure of the skin, the explanation favoured by Pearson, but would rather suggest the action of some internal secretion. The hyperpigmentation of Addison's disease is due to the perverted action of the suprarenal glands which are commonly the seat of the destructive lesions in that disease, and it seems quite possible that normal pigmentation in negroes is due to a somewhat similar cause; light may act not directly on the skin cells but on some tissue or substance which determines the formation of pigment in the skin.

Many of the characteristics of persons living in tropical countries are akin to symptoms occurring in suprarenal insufficiency.

With regard, however, to the factor of abnormality of skin structure brought forward by Pearson, I would again refer to the conditions as seen in the sections of

* [I would venture to suggest that the very facts that the pigment developed in a spot only in this case, and that pigment occurs in localised patches only in piebalds, or in freckles and isolated locks of hair in otherwise complete albinos do indicate a differential structure; the local absence of a fermentwithout a cause for its absence-seems to me an inadequate explanation of leucosis. ED.] 


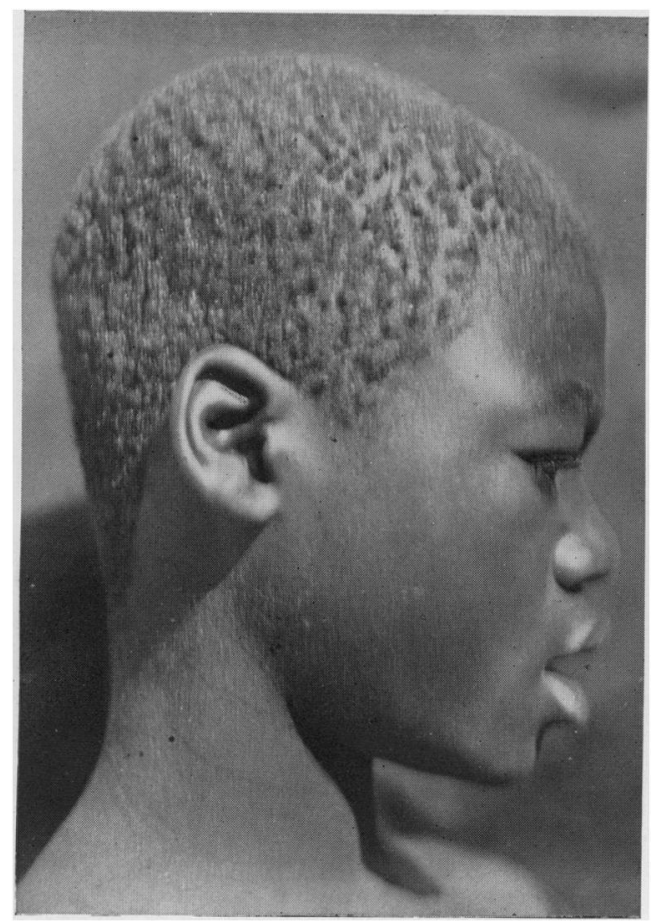

Fig. 1.

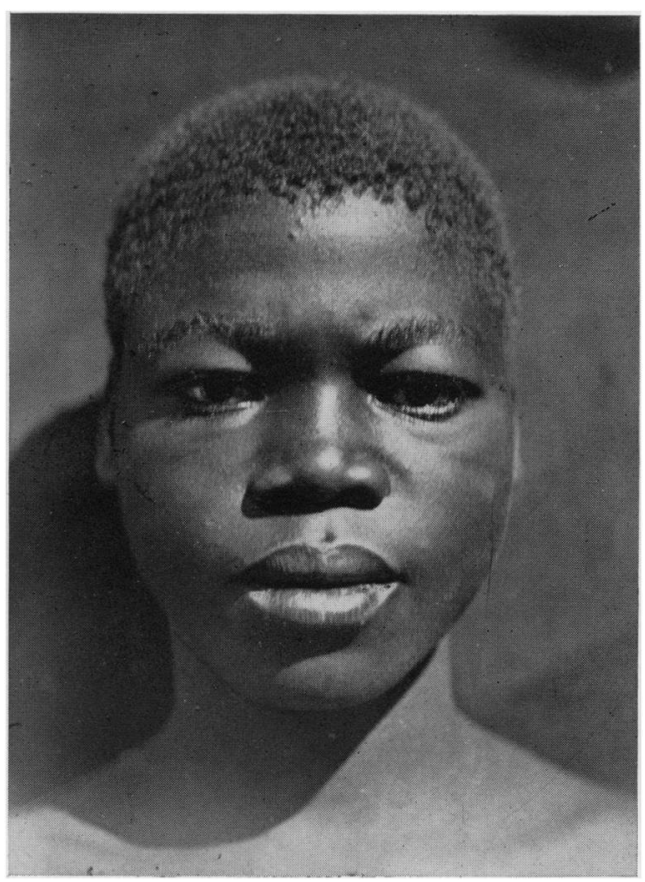

Fig. 2.

Sawali of Ntiya, Mlumbi. Case of Xanthism. See p. 346.

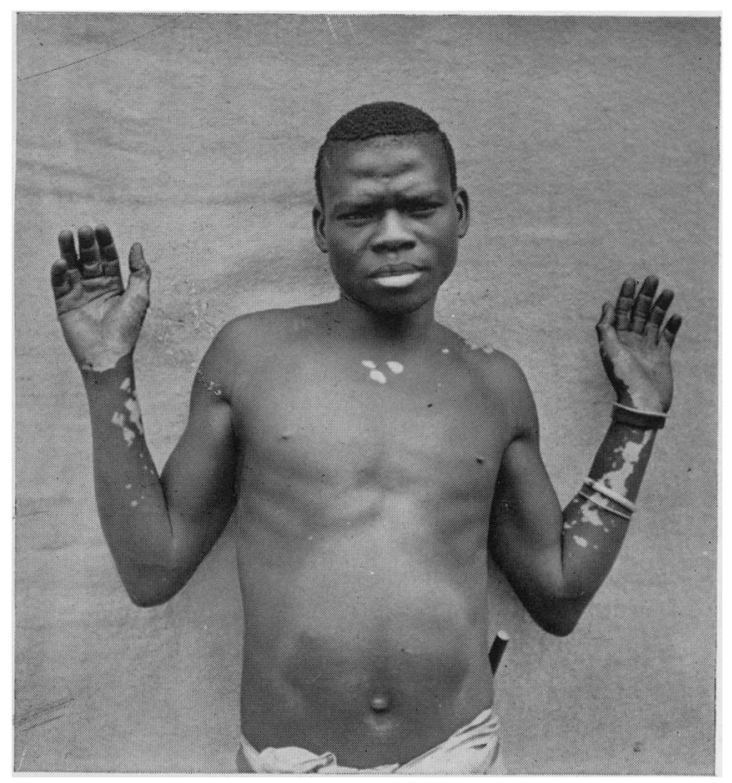

Fig. 3. Ouda of Checkiwere's. Case of Leucoderma. See p. 353.

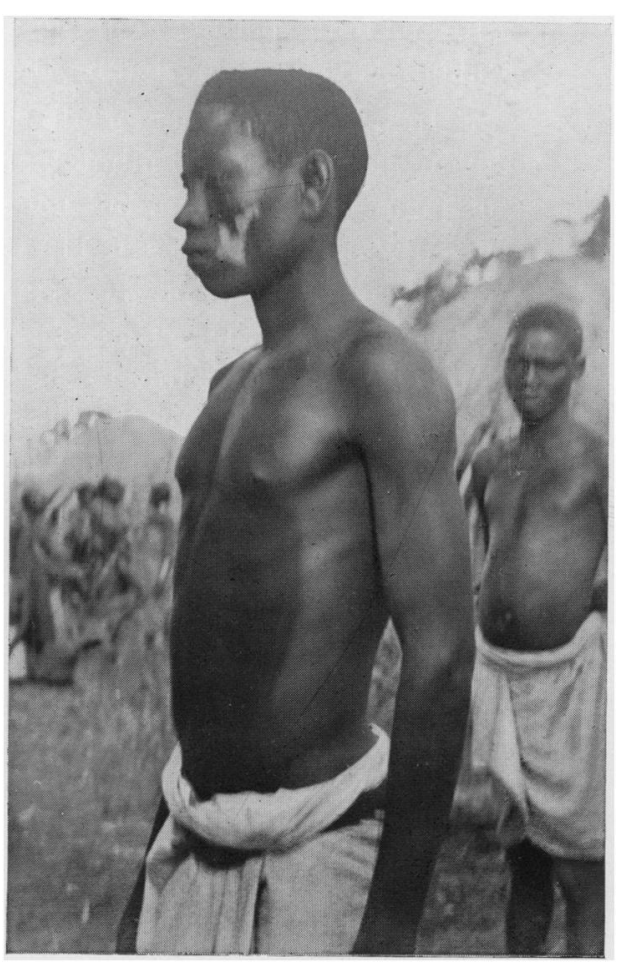

Fig. 4. Daus of Chimwai Village, Dwangwa River. Spotlings. See p. 348. 

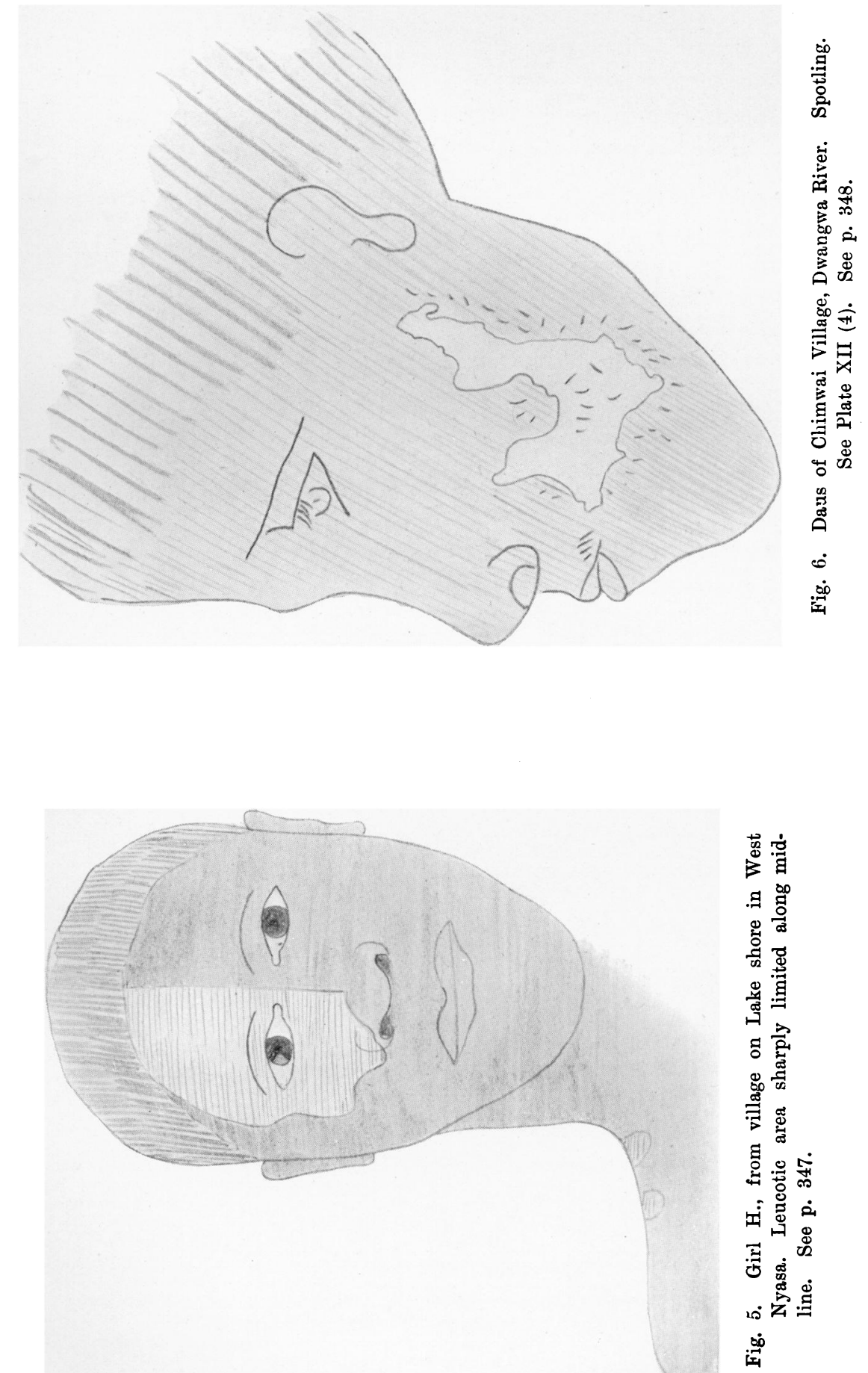


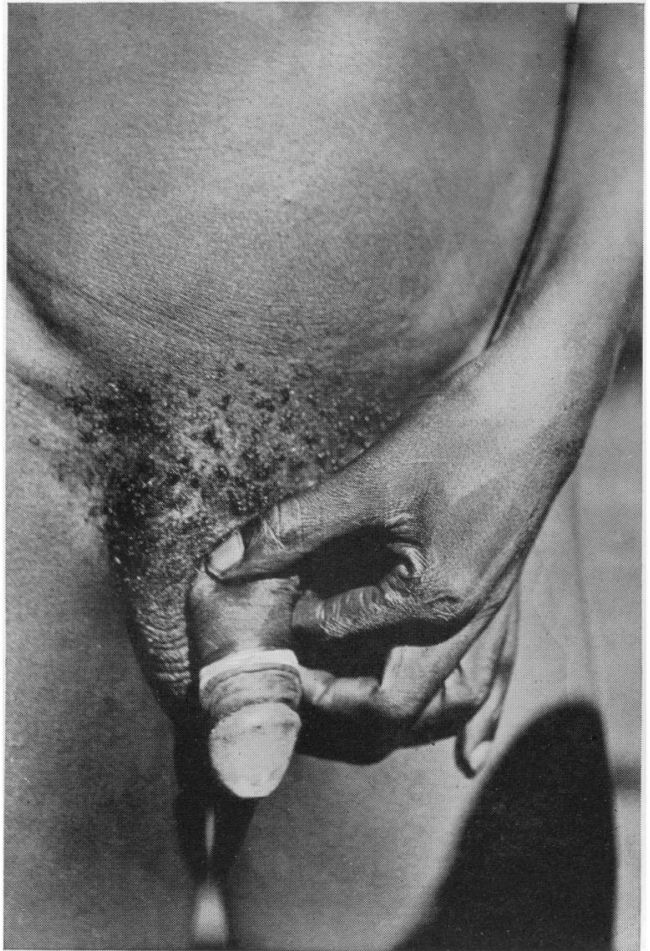

Fig. 7.

Albinotic penis not referred to in text.

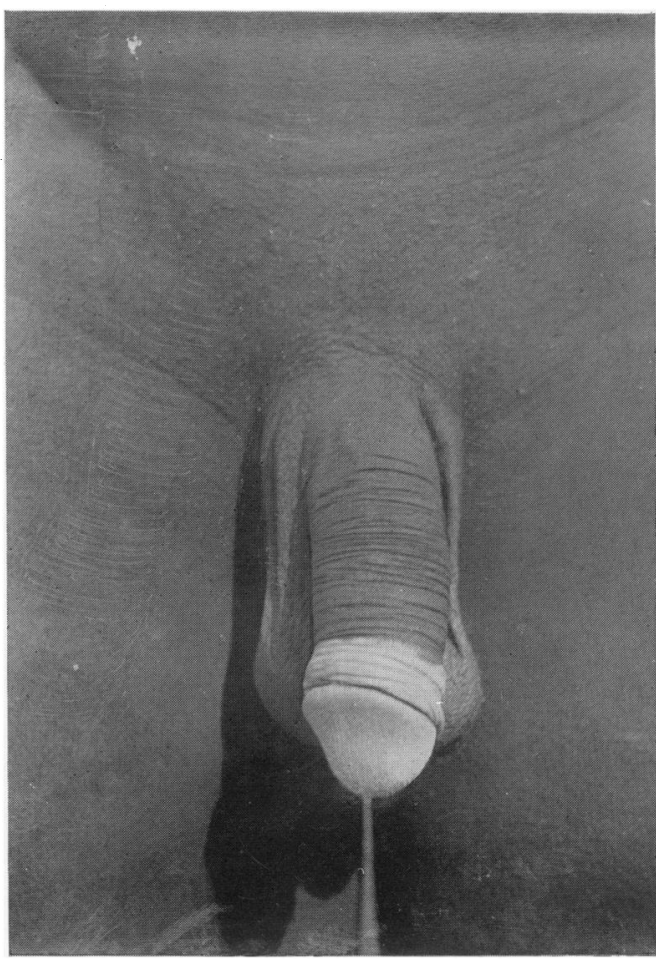

Fig. 9. Binali. Leucosis of glans and prepuce. See p. 351 .

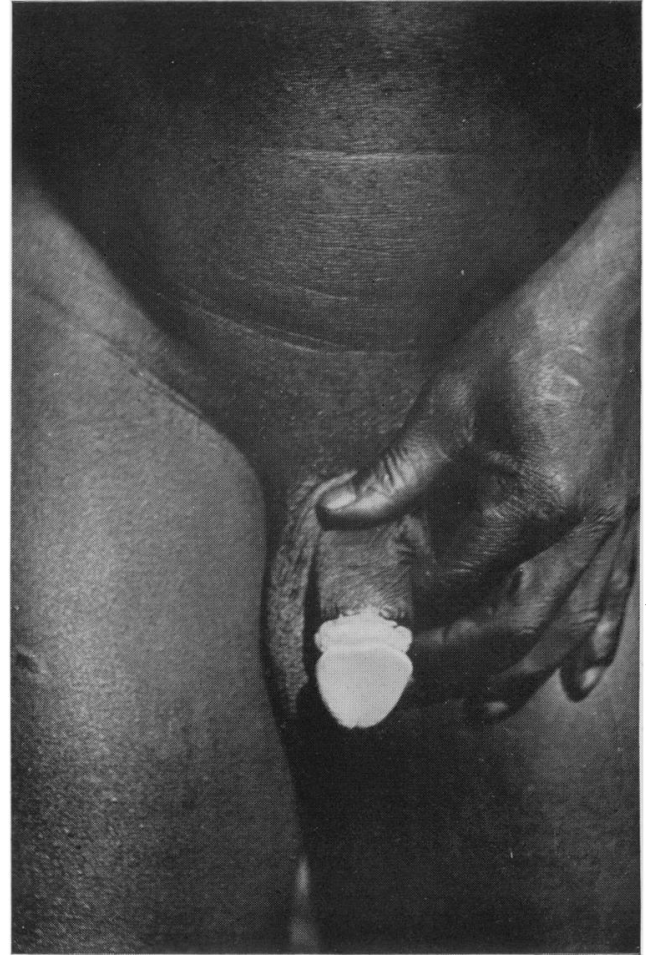

Fig. 8.

Lijuni. Leucosis of glans and inner surface of prepuce after circumcision. See p. 351.

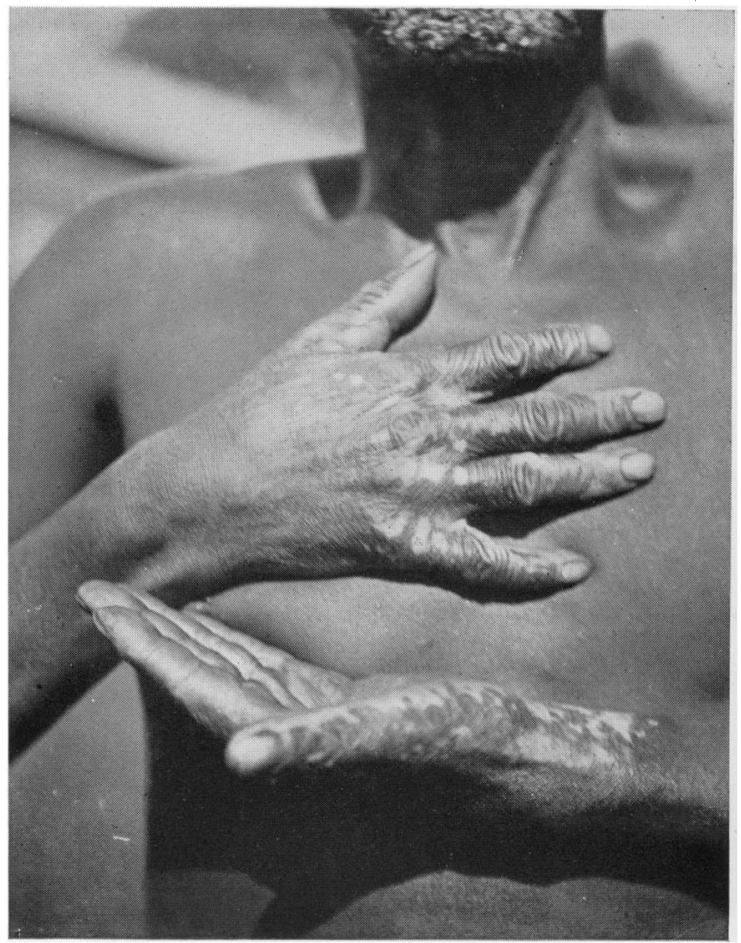

Fig. 10. Licheta, an Angoni of Dedza, Central Prison, Zomba. Case of Ziemann's "Melung." See p. 355 . 


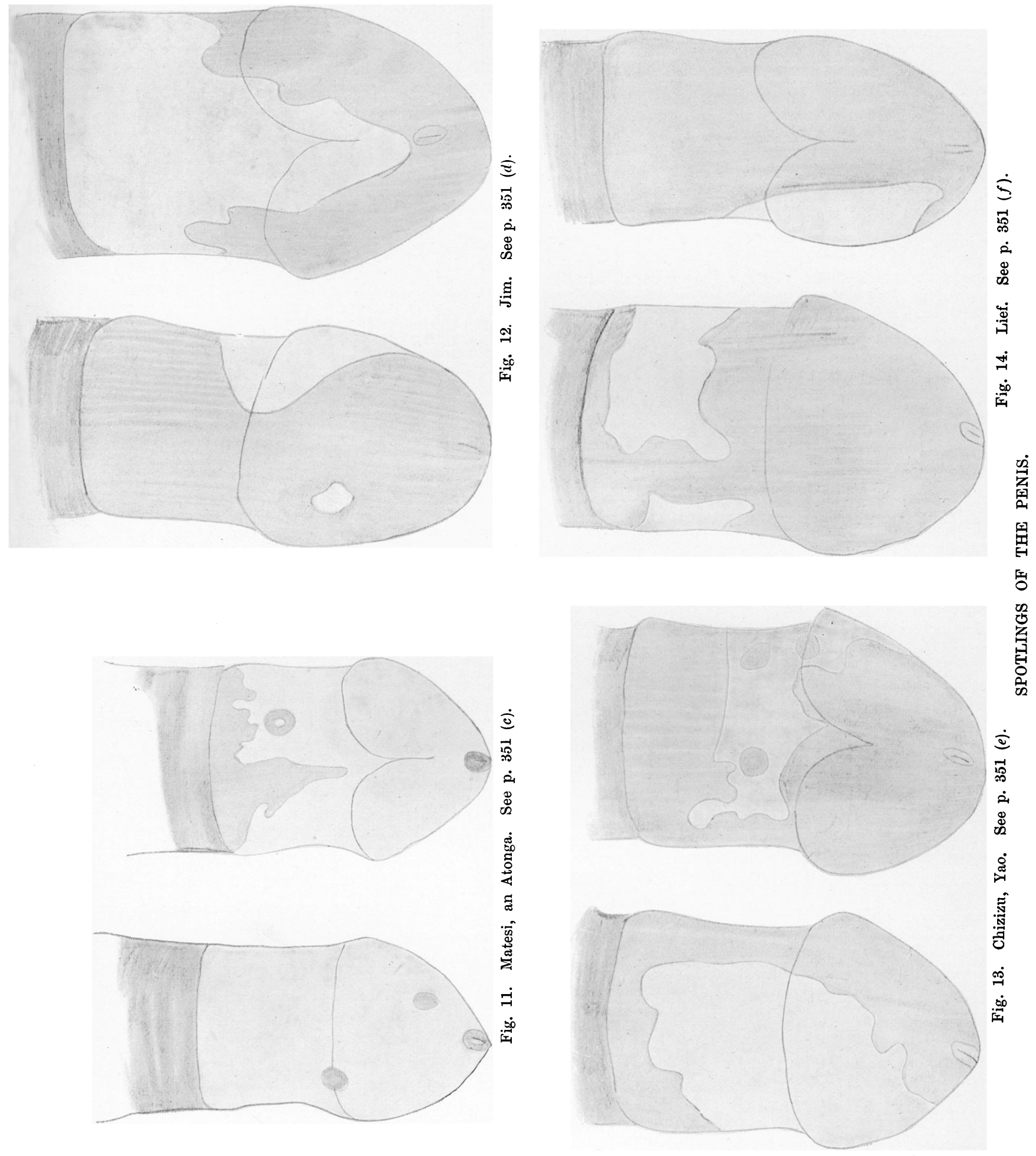



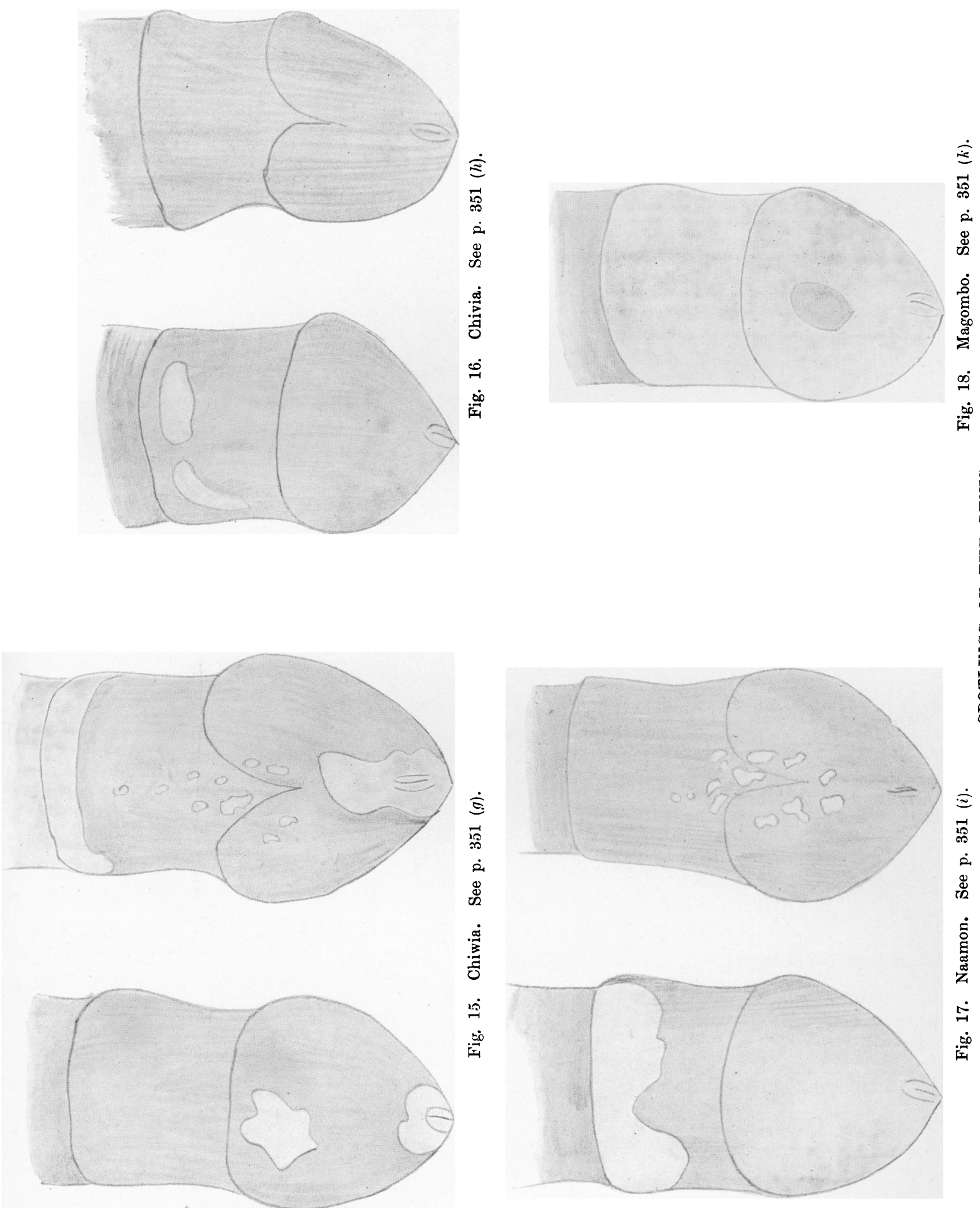

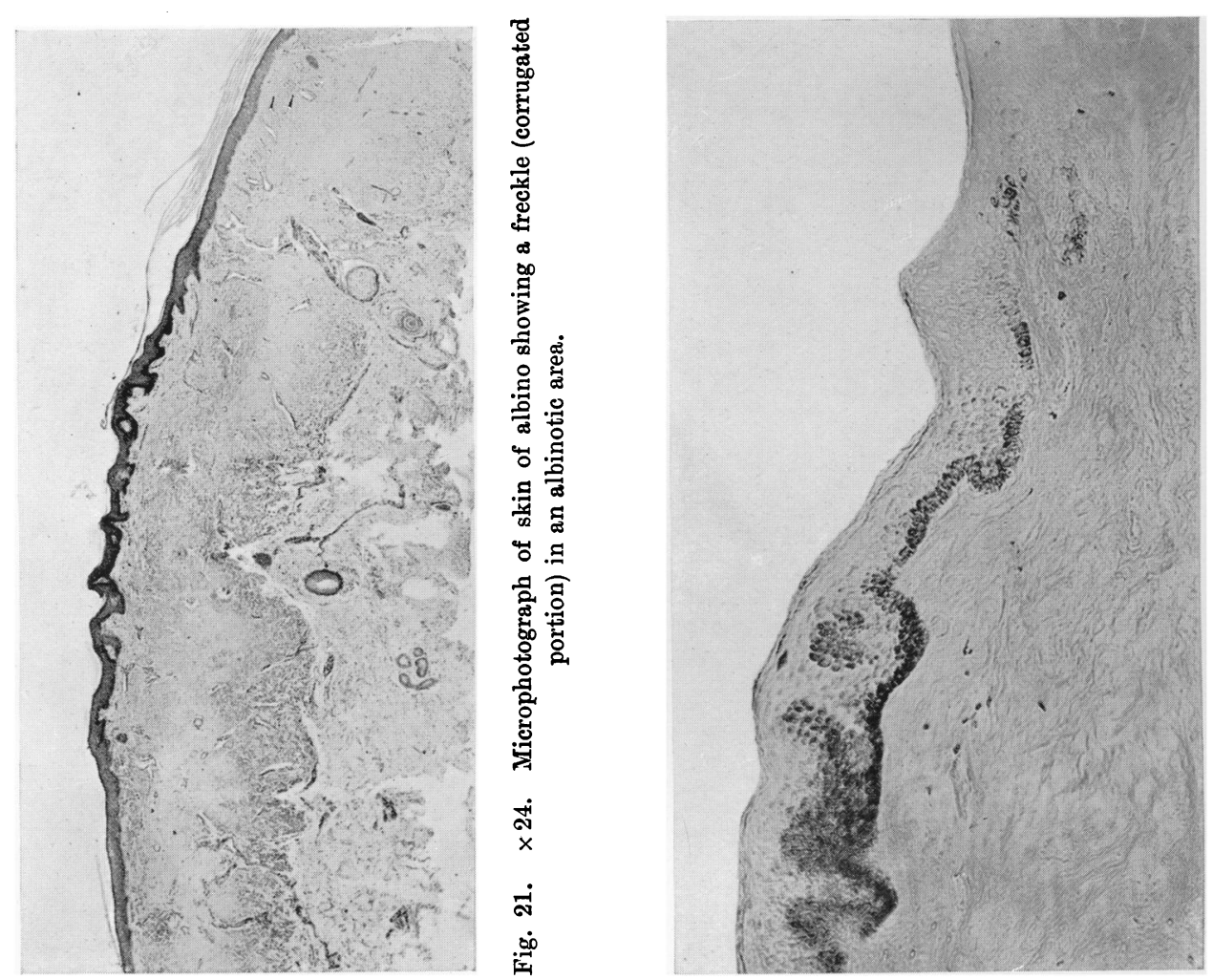

昰恋
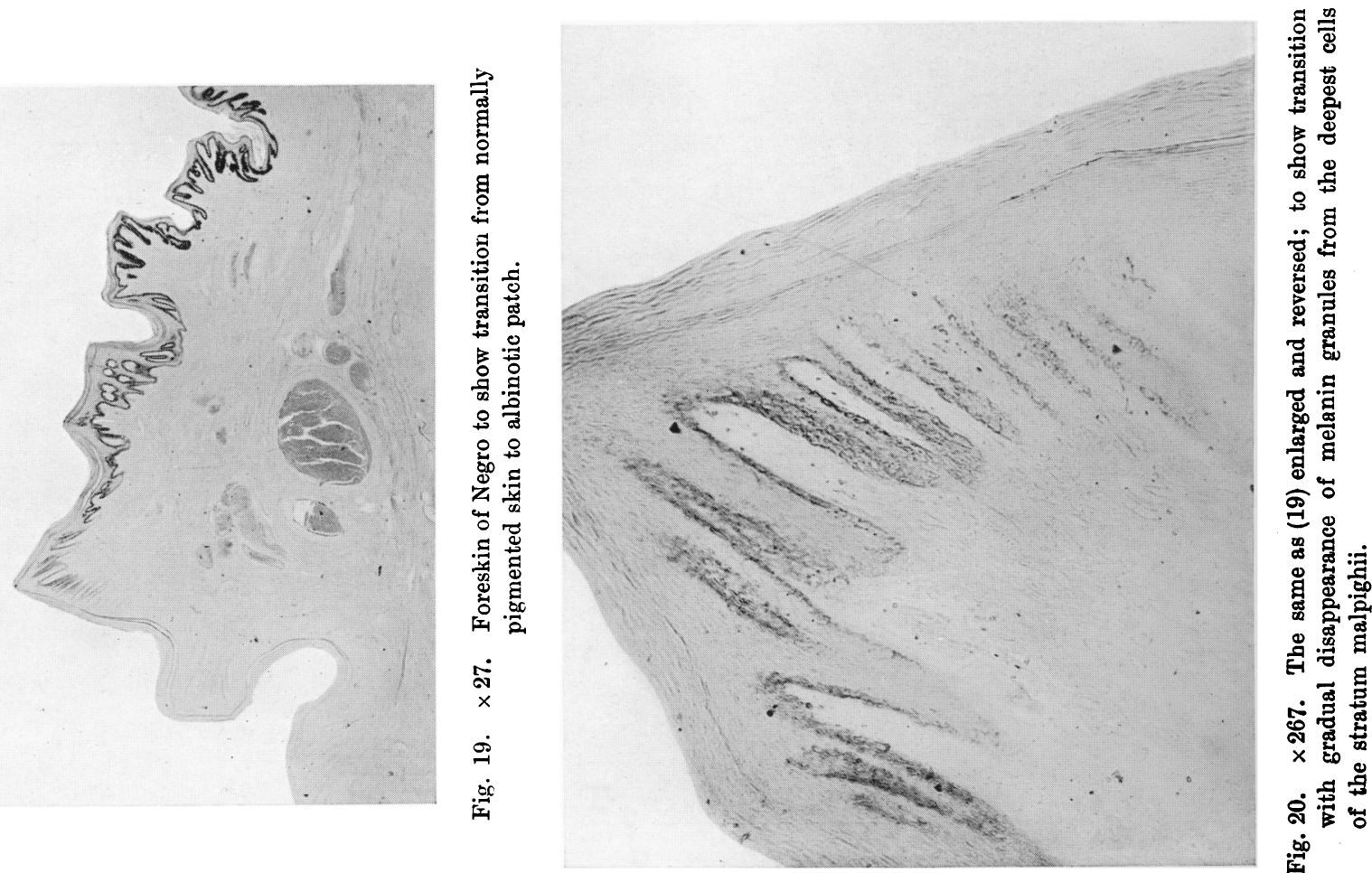


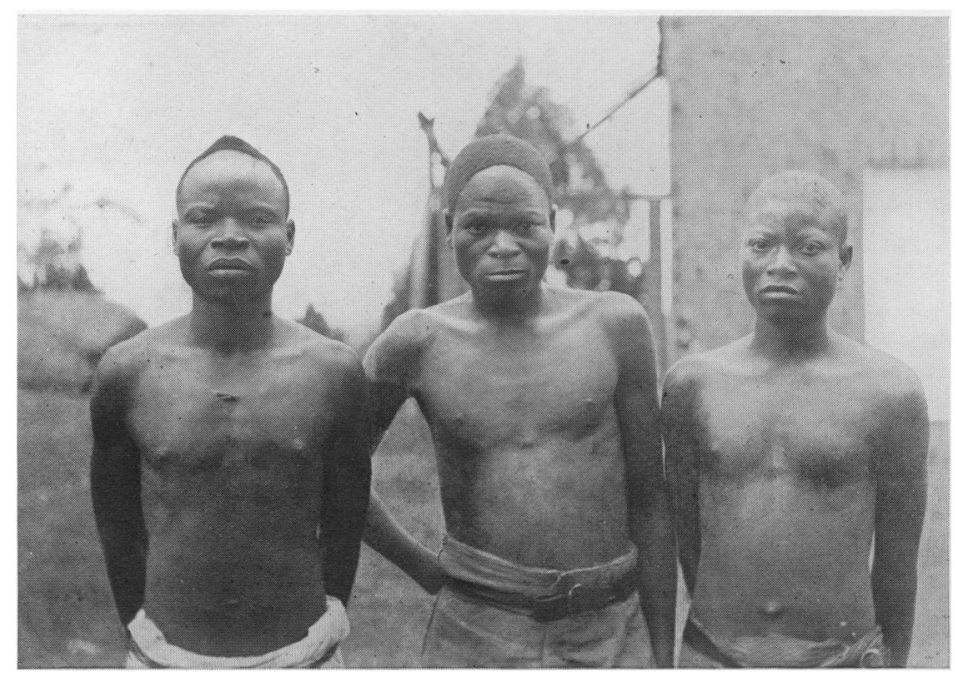

Fig. 23. Normal Native, Moyichandi and Sikumbiri from left to right. Grades of albinism in Nyasaland Natives. See p. 346.

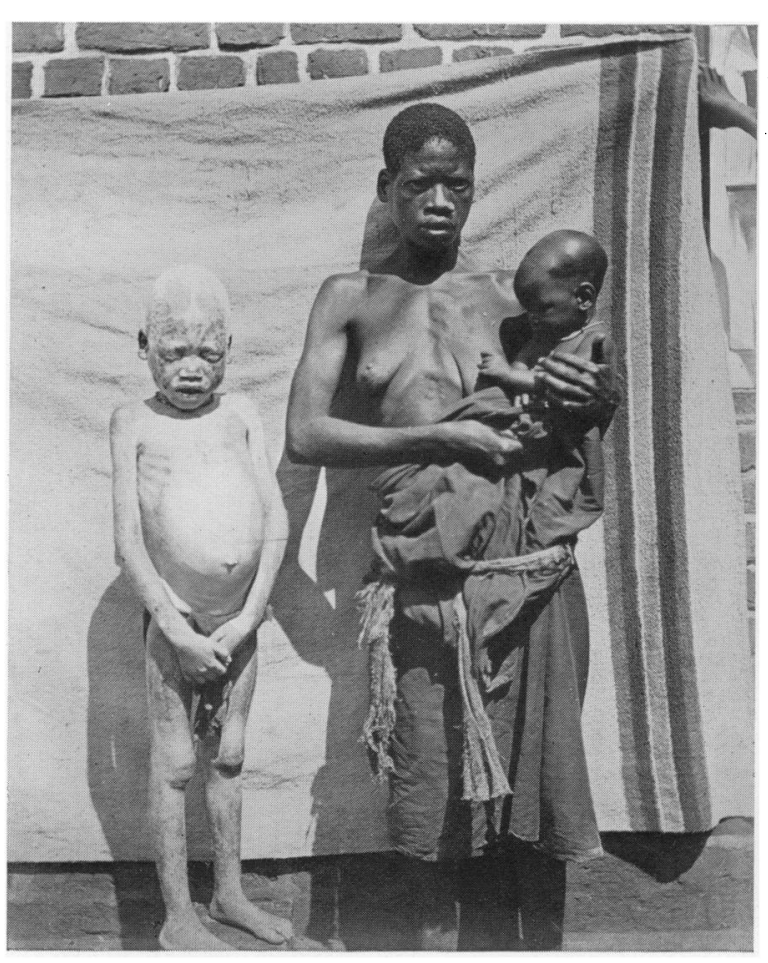

Fig. 24. Chibwana, an albino with mother and sister, from Chikala. See p. 343.

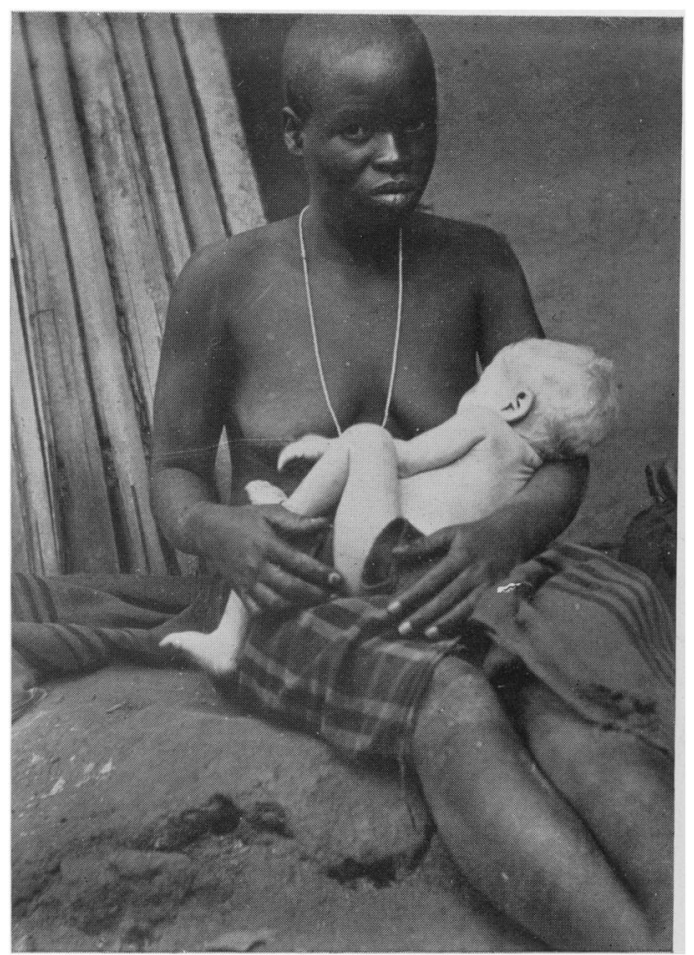

Fig. 25. Alice, an albino baby, and ber mother from Chikanji's village. See p. 339. 


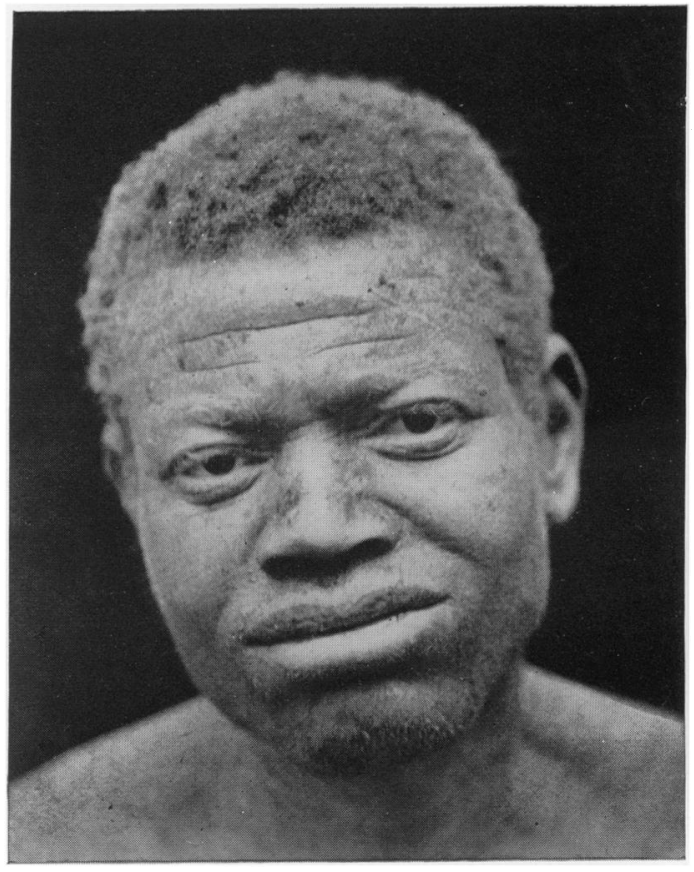

Fig. 26. Head of Pingo, an albino from Chitalu. See p. 341.

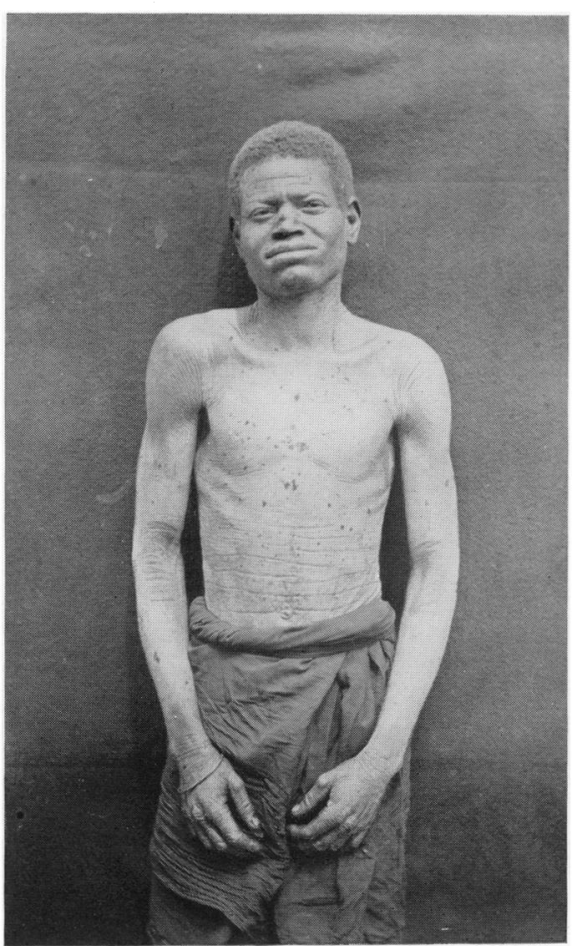

Fig. 27. Pingo, an albino from Chitalu. See p. 341.

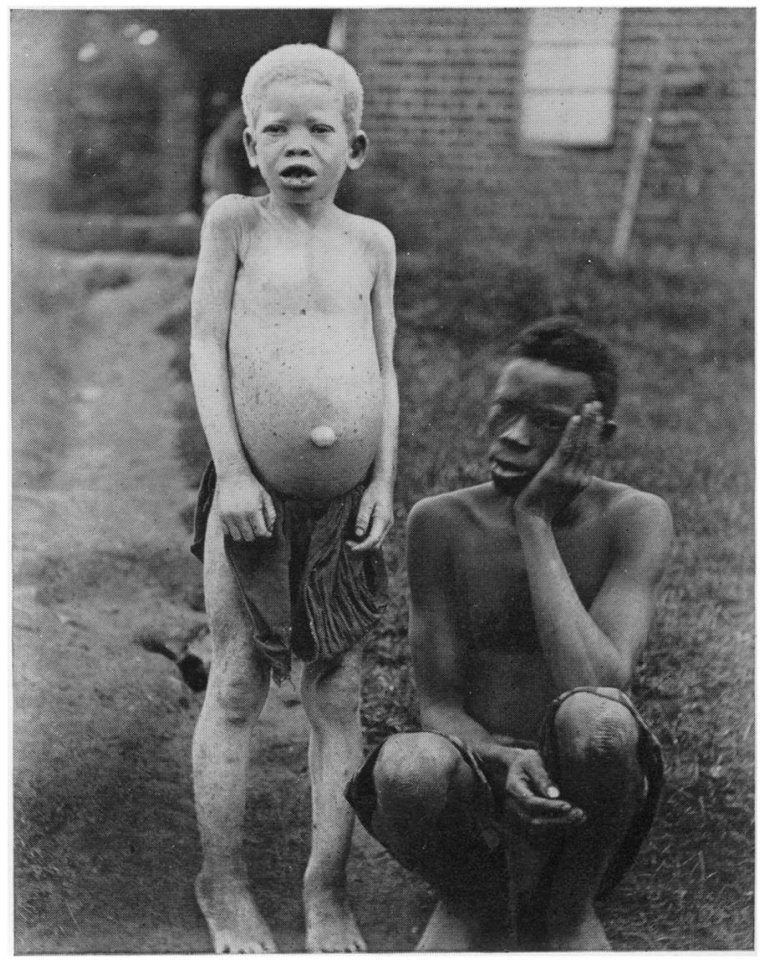

Fig. 28. John, an albino from Mwandanas. See p. 340. 

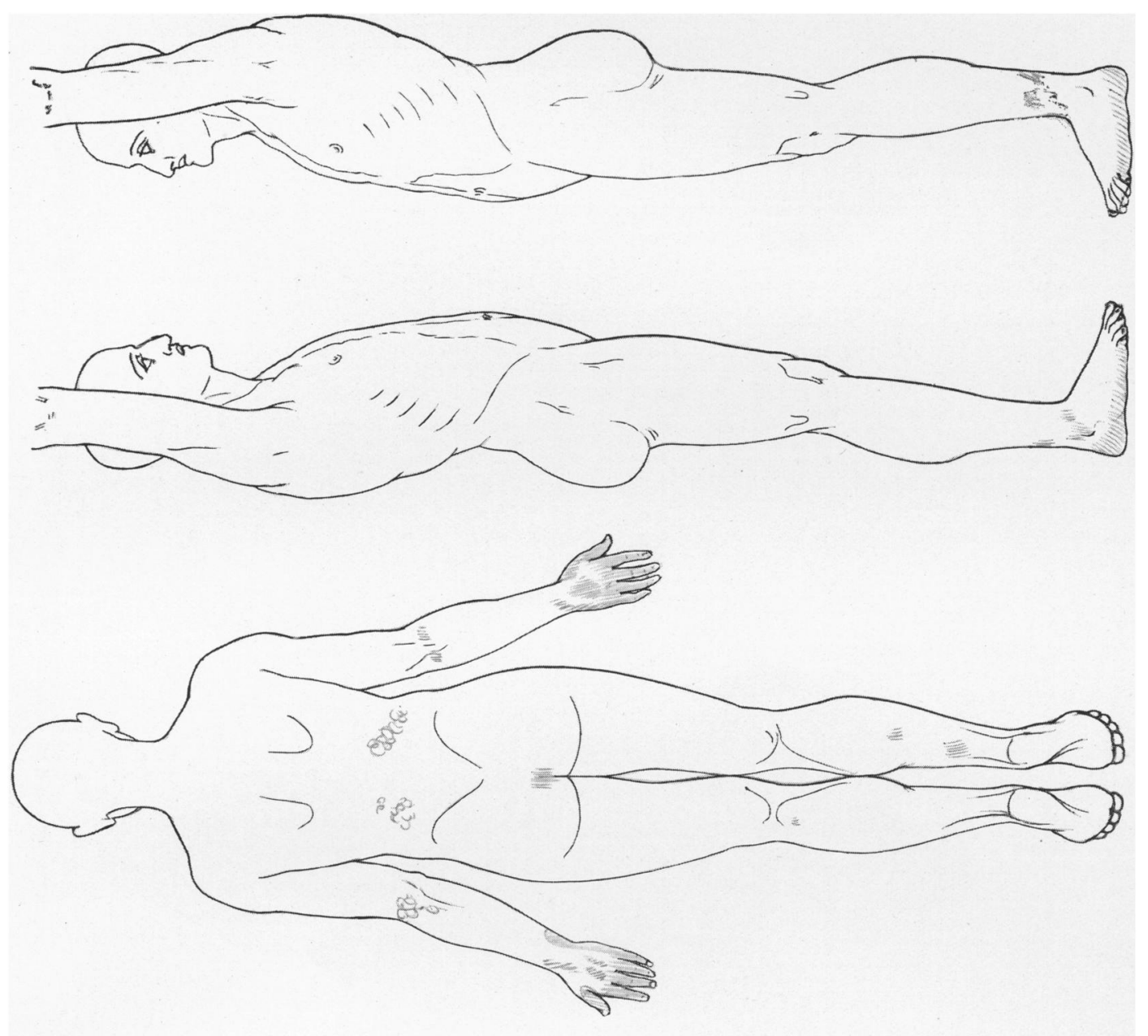

(2)

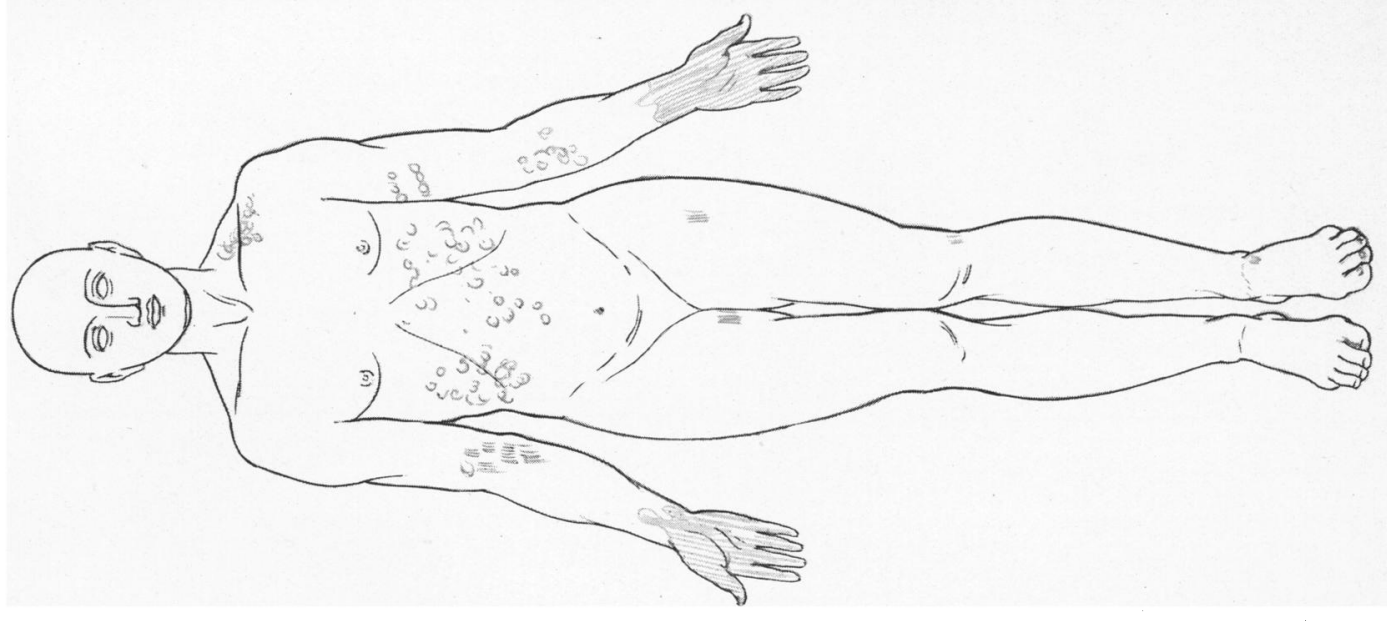

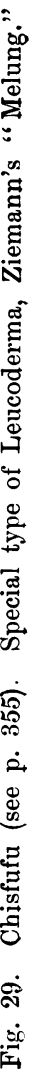



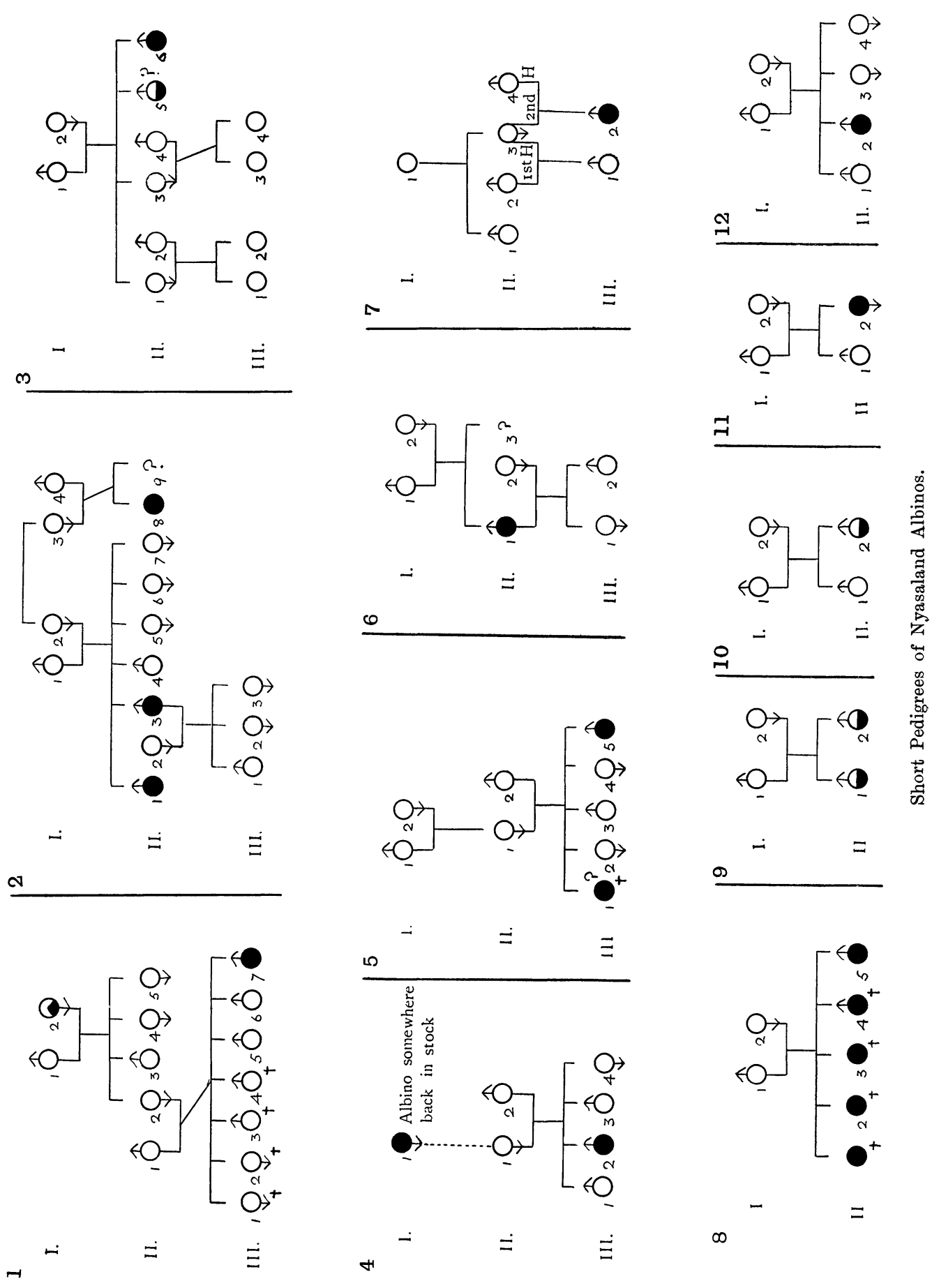
a pigmented spot from an albino, and also to the association of an unusual development of lanugo and of defective teeth with albinism.

The condition of the teeth suggests enamel deficiency, and is one which I did not meet with when examining the teeth of 1500 natives of all ages (not albinos) for statistical purposes.

One of the interesting points which has been brought to light by the investigations of Pearson and others is that in albinotic hair, while granular pigment is absent, diffuse red or yellow pigment is present, and the same is true of some kinds of red hair among Europeans. The relation of this diffuse pigment to granular pigment has not however been I think generally recognised. From the microscopical examination of the various hairs above described I think there can be little doubt that the granular pigment is formed from the diffuse pigment by some process allied to precipitation (compare hair from new-born infant child of Private Jumbe, from Mwana Ngala, from Pamandhe, also from Sawali and Moyichandi)*.

Loss of colour may be accompanied by a reversed process (compare hair from Kause, an old female lunatic).

A similar process may take place in the skin, as evidenced by the band of diffuse colouration beyond the area of granular pigment found in the section of prepuce (Lijuni).

The plan of the localised leucotic patches may be palaeogenetic as suggested by piebalds with white belly markings and flare, or there may be a segmental distribution (see case of girl $H$. in whom the area is limited strictly by the mid-line).

One believes therefore that pigmentation is due to an internal secretion, that light and other climatic conditions are determining factors, that a ferment may play some part, that the pigmentation of the skin is due to melanin produced in the cells of the epidermis, and that therefore structure also must be taken into account, that in albinism in its various grades and in dynamic forms of leucosis one or other or several of these factors have to be taken into account.

Addendum. One may say that in ordinary natives the colour of the iris is always some shade of brown. There is one exception. The iris in a few otherwise ordinarily dark natives may be of a greenish colour with no element of brown, a very striking feature, and known as "jeri-jeri" by the natives, who say it resembles the eye of a cat.

* [It seems difficult to establish such a conclusion until very elaborate chemical investigations of the two types of pigment, lipochrome and melanin have been made. The microscopic investigation of hundreds of samples of hair, albinotic and non-albinotic, are given in Chapter VIII of the Monograph, but they tell so far as much in favour of the independence as of the dependence of the two types of pigment. ED.] 